\title{
Phosphodiesterase-5 (PDE-5) Inhibitors as Emergent Environmental Contaminants: Advanced Remediation and Analytical Methods
}

\author{
Giuliana Bianco ${ }^{1}{ }^{\mathbb{D}}$, Luca Foti ${ }^{1}$, Raffaella Pascale ${ }^{2}{ }^{(D)}$, Filomena Lelario ${ }^{1}$, Donatella Coviello ${ }^{1}$, Monica Brienza ${ }^{1}$, \\ Sabino Aurelio Bufo ${ }^{1,3}$ (D) and Laura Scrano ${ }^{4, *(\mathbb{D})}$ \\ 1 Department of Sciences, University of Basilicata, Via dell'Ateneo Lucano 10, 85100 Potenza, Italy; \\ giuliana.bianco@unibas.it (G.B.); luca.foti@unibas.it (L.F.); filomena.lelario@unibas.it (F.L.); \\ donatella.coviello@unibas.it (D.C.); monica.brienza@unibas.it (M.B.); sabino.bufo@unibas.it (S.A.B.) \\ 2 Gnosis by Lesaffre, Research Laboratory, 75015 Pisticci, Italy; raff.pascale@gmail.com \\ 3 Department of Geography, Environmental Management \& Energy Studies, University of Johannesburg, \\ Johannesburg 2092, South Africa \\ 4 Department of European Cultures (DICEM), University of Basilicata, 75100 Matera, Italy \\ * Correspondence: laura.scrano@unibas.it
}

check for updates

Citation: Bianco, G.; Foti, L.; Pascale, R.; Lelario, F.; Coviello, D.; Brienza,

M.; Bufo, S.A.; Scrano, L.

Phosphodiesterase-5 (PDE-5)

Inhibitors as Emergent

Environmental Contaminants: Advanced Remediation and Analytical Methods. Water 2021, 13, 2859. https://doi.org/10.3390/ w13202859

Academic Editor: Jiangyong Hu

Received: 2 September 2021

Accepted: 9 October 2021

Published: 13 October 2021

Publisher's Note: MDPI stays neutral with regard to jurisdictional claims in published maps and institutional affiliations.

Copyright: (c) 2021 by the authors. Licensee MDPI, Basel, Switzerland. This article is an open access article distributed under the terms and conditions of the Creative Commons Attribution (CC BY) license (https:/ / creativecommons.org/licenses/by/ $4.0 /)$.

\begin{abstract}
Pharmaceuticals, fundamental in therapy and the prevention of known pathologies, are responsible for environmental pollution. These substances, called "emerging contaminants," are harmful to human health because they enter the environment in quantities exceeding the natural selfcapacity purification of the ecosystems. Furthermore, wastewater treatment plants (WWTPs) cannot remove these substances, which can undergo chemical/biological transformations in the environment, thus forming by-products, sometimes more toxic than the parent molecules; successively, they move into rivers and could reach the drinking water supplies. All these phenomena represent a severe public health problem. Therefore, the Water Framework Directive by European Union imposed the monitoring of drugs' levels in aqueous matrices. Every two years, the EU carefully updates the list of potential water pollutants, called the Watch List, including pharmaceuticals, to evaluate their risk on the aquatic environment. The last Commission Implementing Decision (EU 2018/840) comprises several substances of primary concern. In addition, the scientific community is giving particular attention to other pharmaceuticals not yet on the Watch list, whose markets are in growth; particularly, the Phosphodiesterase 5 (PDE-5) inhibitors used for the pharmaceutical treatment of erectile dysfunction (ED) in men. This review discusses the presence of PDE- 5 inhibitors in environmental systems, their toxic effects, the different kinds of removal, and the analytical methods normally adopted for their detection. In addition, the study helps figure out the best possible strategy to tackle pharmaceutical pollution by using analytical and advanced diagnostic methods.
\end{abstract}

Keywords: phosphodiesterase-5 (PDE-5) inhibitors; environment contamination; wastewater plants (WWTPs); advanced oxidation process (AOP); eco-toxicity; analytical methods

\section{Introduction}

Emerging pollutants (EPs) are synthetic or naturally occurring compounds not commonly examined in the environment [1]. Still, they can enter ecosystems and cause recognised or supposed adverse effects on ecology and human health [1]. Moreover, they undergo chemical/biological transformations, forming by-products sometimes more toxic than the parent molecules. The final issue is the accumulation of original and transformed substances in water bodies [2]. In particular, Zuccato et al. [3] evidenced the presence in ground and surface waters of drugs and pharmaceuticals having polar structures, probably coming from WWTP effluents.

When absorbed by the body, a pharmaceutical substance enters the circulation and distributes to reach the target site to perform its function [2,4]. When the metabolism 
process is activated, some molecules reach the target site and others transform into inactive metabolites, which are substances no longer producing effects into the body. Many medicines, however, are excreted without being metabolised or at least without being completely inactivated [2,5]. These, together with sewage, reach the WWTP, where organic loads degrade and water is purified. Unfortunately, these structures are often not designed to degrade active substances of pharmaceutical origin, which, therefore, once again manage to resist, unharmed, and maintain their effectiveness. As a result, the purified water (still rich in active ingredients) flows into the receiving channels, carrying a load of pollutants to rivers and lakes. Thus, tons of active substances such as antibiotics, anti-neoplastic, estrogens and others are poured into surface waters [6,7]. Once in the environment, the drug eventually degrades or can persist very long, resulting in noticeable build-ups [8]. In the sediments of some Italian rivers such as the Po, Lambro and Adda rivers, as well as in the aqueducts of the towns of Varese and Lodi, traces of various drugs were present in different amounts, including antibiotics (lincomycin and erythromycin), anticancer (cyclophosphamide), anti-inflammatory (ibuprofen), diuretics (furosemide) and antihypertensive (atenolol) drugs [9]. The existence of these compounds in environmental systems is of concern since they constitute a complex assortment, which could induce the occurrence of undesirable synergistic effects and could be responsible for many health adverse effects such as allergies, development of antibiotic-resistance phenomena, disorders of the endocrine system, cytolytic or cytostatic effects and others [10-12].

The European Parliament regulated with the Directive 2008/105/EC environmental quality standards in the field of water policy and the range of inorganic and organic contaminants to be monitored in water [13]. The last Commission Implementing Decision (EU 2018/840) included several new substances of primary concern [14]. The scientific community is also paying attention to other pharmaceuticals having a growing market in the last years: phosphodiesterase-5 (PDE-5) inhibitors (sildenafil citrate, tadalafil, avanafil and vardenafil marketed as Viagra ${ }^{\circledR}$, Cialis $^{\circledR}$, Spedra ${ }^{\circledR}$ and Levitra ${ }^{\circledR}$ ) (Figure 1) titled for the cure of erectile dysfunction (ED) [15].

ED, an increasing disorder [16], affects 25 to 35 million men over 18 years in Europe [17]. Following many statistic studies, it seems caused by (i) neurologic (deficit in nerve signalling to the "corpora cavernosa"), (ii) psychological (depression, stress, anxiety) or (iii) endocrinologic (low testosterone levels or other hormone imbalances) problems, but most often, it is the result of cardiovascular disease associated with other health problems such as diabetes, smoking, hypertension, hyperlipidaemia, metabolic syndrome and other [18-20]. Pharmaceuticals used to reduce this disorder act as phosphodiesterase-5 (PDE-5) inhibitors, a family of enzymes typically active in cyclic guanosine monophosphate (cGMP) degradation. The inhibition of PDE-5 results in the intracellular accumulation of cGMP, which plays a central role in signal transduction and regulates several physiological responses. In the penis, cGMP induces corpora cavernosa smooth muscle relaxation and thus increases the blood supply, leading to the erection of the penis. PDE-5 inhibitors prevent the degradation of cGMP, thus enhancing and prolonging erections and increasing sexual satisfaction [21]. ED products are medicines approved by the US Food and Drug Administration. The European Medicines Agency (EMA) approved Viagra, Cialis and Levitra in 1998, 2002 and 2003, respectively. The last one was Spedra in 2013. Doctors also prescribe these compounds for other syndromes such as arterial hypertension, coronary artery disease and benign prostatic hyperplasia (BPH) [22,23]. 


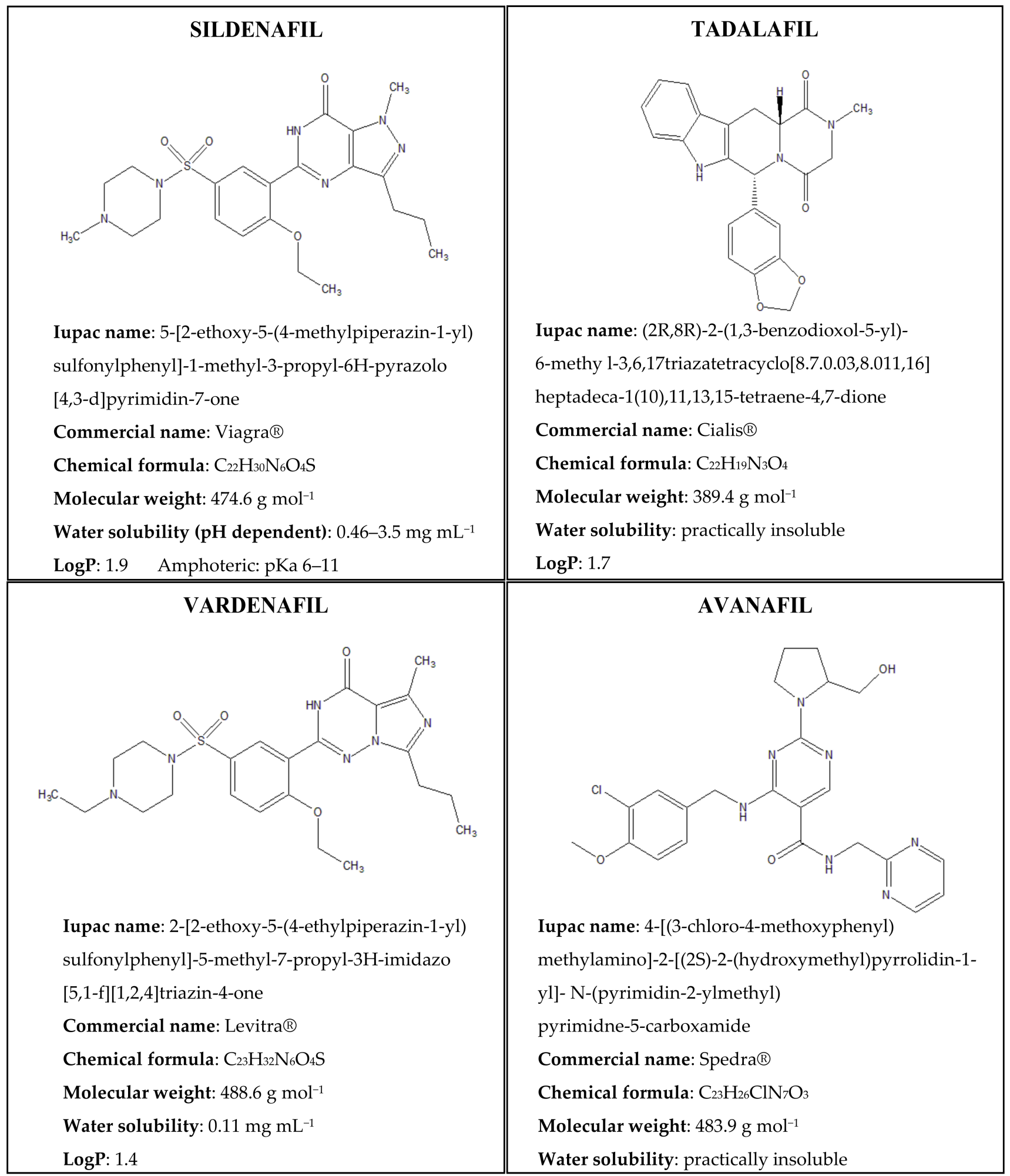

Figure 1. Structures, chemical formula and available solubility and partition properties of the primarily used PDE5 inhibitors.

According to the 2018 annual report prepared by the Italian Medicines Agency (AIFA), these compounds' consumption had increased over time from 2.9 DDD (Defined Daily Dose assumed per 1000 inhabitants in the referred year) in 2014 to 3.6 DDD in 2018 (for example, tadalafil has risen by $3.7 \%$ since 2017 , becoming the fourth most-used drug, preceded only by paracetamol, lorazepam and alprazolam). Patients usually tend to hide 
their problems and the related pharmaceutical cure and choose the Internet as a way of purchasing to avoid medical prescriptions. However, Chiang et al. [24] report that illicit trading with products from the Internet and with counterfeit medicines is increasing [25], and the individuals purchasing medicines via the Internet are not wholly conscious of the risks for health concerning the quality of these products such as the possible presence of toxic impurities [26]. The high consumption of these substances, globally accomplished by legal and illegal ways, legitimates thinking that they can pose a severe threat to ecosystems and human health [27].

\section{Aim and Review Methodology}

This review deals with the presence of pharmaceuticals used as PDE-5 inhibitors in the environment and their toxic effects, including a standpoint of the different removal technologies and analytical methods normally adopted for their detection in environmental samples. The rationale behind the literature analysis is the prompter for the reviewing methodology, as follows: (i) PDE-5 inhibitors are widely used for different therapeutic applications; (ii) they are also marketed illegally due to their ease of availability without prescriptions outside the official health system; (iii) urban wastewater contains not only residues of the parent molecules but also their human metabolic products; (iv) the relative mixture of drugs can undergo biotic and abiotic degradation, causing new concerns of eco-toxicity. This review offers an overview of the highlighted issues, starting from the contamination sources, passing through the ability of water purification plant systems to remove these contaminants, including an evaluation of the parent molecules and byproducts toxicity. Reviewing the analytical methods used to determine these substances and identifying derivatives is essential for the article's completeness, emphasising analytical methods that offer the highest resolution and accuracy.

We consulted a total of 110 articles using several keywords: PDE- 5 inhibitors, the status of the environmental contamination, wastewater treatment plants (WWTPs), sewage treatment plants (STPs), advanced oxidation process (AOPs), eco-toxicity and analytic diagnostic methods.

\section{Source of PDE-5 Inhibitors in the Environment}

According to the "anatomical therapeutic and chemical" (ATC) classification system, PDE-5 inhibitors are available in the class ATC code G04BE. The four most significant inhibitors used are sildenafil $\left(\right.$ Viagra $\left.{ }^{\circledR}\right)$, tadalafil $\left(\right.$ Cialis $\left.^{\circledR}\right)$, vardenafil (Levitra ${ }^{\circledR}$ ) and avanafil $\left(\right.$ Spedra $\left.{ }^{\circledR}\right)$, all approved by Food and Drug Administration (FDA). In addition, there are other pharmaceuticals that are non-FDA approved and commercially available in some countries, such as udenafil $\left(\mathrm{Zydena}^{\circledR}\right)$ in South Korea and Malaysia, mirodenafil (Mvix $\left.{ }^{\circledR}\right)$ in South Korea and lodenafil carbonate $\left(\right.$ Helleva $\left.^{\circledR}\right)$ in Brazil [28].

Sildenafil $\left(\mathrm{C}_{22} \mathrm{H}_{30} \mathrm{~N}_{6} \mathrm{O}_{4} \mathrm{~S}\right)$ was discovered in 1989 by the Pfizer Cardiovascular Research and Development Group (Sandwich, Kent, UK) during research focused on identifying PDE- 5 inhibitors to treat angina pectoris due to the abundant presence of the PDE-5 enzymes in platelets and vascular smooth muscle cells. It showed low effectiveness on angina pectoris tests and penile erection as the primary collateral effect [29]. The FDA, in 1998, approved sildenafil for erectile dysfunction treatments and then in 2005, the European Medicine Agency (EMA) approved it for class II and class III pulmonary hypertension treatments. Vardenafil $\left(\mathrm{C}_{23} \mathrm{H}_{32} \mathrm{~N}_{6} \mathrm{O}_{4} \mathrm{~S}\right)$ and tadalafil $\left(\mathrm{C}_{22} \mathrm{H}_{19} \mathrm{~N}_{3} \mathrm{O}_{4}\right)$ were introduced clinically in 2003, while avanafil $\left(\mathrm{C}_{23} \mathrm{H}_{26} \mathrm{ClN}_{7} \mathrm{O}_{3}\right)$ in 2013. Although the structural differences between these compounds are minor, they have different pharmacokinetic properties (absorption, distribution, metabolism and excretion). In addition, they can exert their activity also on other PDE-types, as reported in Table 1 [30].

All four PDE-5 inhibitors are rapidly absorbed from the gastrointestinal tract and show broadly similar $\mathrm{T}_{\max }$, except for tadalafil which has the longest Tmax. Peak plasma concentration $\left(C_{\max }\right)$ of sildenafil is reached in less than $1 \mathrm{~h}$ [31]. Vardenafil and avanafil have sim- 
ilar pharmacokinetics to sildenafil, with Tmax approximately $1 \mathrm{~h}$ [32] and 30-45 $\min$ [33].

Tadalafil reaches its maximum concentration in plasma after about $2 \mathrm{~h}$ [34].

Sildenafil, vardenafil and avanafil have a terminal half-life $\left(T_{1 / 2}\right)$ of between 4 and $5 \mathrm{~h}$, and tadalafil has a half-life of $17.5 \mathrm{~h}$.

Table 1. Pharmacokinetic parameters of PDE-5 inhibitors (re-edited from [30]).

\begin{tabular}{|c|c|c|c|c|}
\hline Parameters/Drugs & Sildenafil (Viagra) & Vardenafil (Levitra) & Tadalafil (Cialis) & Avanafil (Spedra) \\
\hline Bioavailability & $\begin{array}{l}\text { 41\% (mean) } \\
25-63 \% \text { (range) }\end{array}$ & $15 \%$ (mean) & - & - \\
\hline $\mathrm{T}_{\max }$ & $\begin{array}{l}1 \mathrm{~h} \text { (median) } \\
0.5-2 \mathrm{~h} \text { (range) }\end{array}$ & $\begin{array}{l}1 \mathrm{~h} \text { (median) } \\
0.5-2 \mathrm{~h} \text { (range) }\end{array}$ & $\begin{array}{l}2 \mathrm{~h} \text { (median) } \\
0.5-6 \mathrm{~h} \text { (range) }\end{array}$ & $0.5-0.75$ h (range) \\
\hline Protein binding & $96 \%$ & $95 \%$ & $94 \%$ & $99 \%$ \\
\hline Metabolism & $\begin{array}{l}\text { Major: CYP3A4 } \\
\text { Minor: CYP2C9 }\end{array}$ & $\begin{array}{l}\text { Major: CYP3A4 } \\
\text { Minor: CYP3A5, CYP2C }\end{array}$ & CYP3A4 & $\begin{array}{l}\text { Major: CYP3A4 } \\
\text { Minor: CYP2C }\end{array}$ \\
\hline $\begin{array}{l}\text { Active metabolite } \\
(\% \text { effect })\end{array}$ & $\begin{array}{l}\text { Yes }(20 \%) \\
\text { N-demethylation }\end{array}$ & $\begin{array}{l}\text { Yes }(7 \%) \\
\text { Demethylation }\end{array}$ & No & $\begin{array}{l}\text { Yes }(4 \%) \\
\text { Methylation, glucuronidation }\end{array}$ \\
\hline Half-life $\left(\mathrm{T}_{1 / 2}\right)$ & $4 \mathrm{~h}$ & $4-5 \mathrm{~h}$ & $17.5 \mathrm{~h}$ & $5 \mathrm{~h}$ \\
\hline Elimination & $\begin{array}{l}80 \% \text { faeces } \\
13 \% \text { urine }\end{array}$ & $\begin{array}{l}91-95 \% \text { faeces } \\
2-6 \% \text { urine }\end{array}$ & $\begin{array}{l}61 \% \text { faeces } \\
36 \% \text { urine }\end{array}$ & $\begin{array}{l}62 \% \text { faeces } \\
21 \% \text { urine }\end{array}$ \\
\hline $\begin{array}{l}\text { Ingestion with } \\
\text { high-fat meals }\end{array}$ & $\begin{array}{l}\downarrow \mathrm{C}_{\max } 29 \% \\
\uparrow \mathrm{T}_{\max } \text { by } 1 \mathrm{~h}\end{array}$ & $\downarrow C_{\max } 18-50 \%$ & Not affected & $\begin{array}{l}\downarrow \mathrm{C}_{\max } 24-39 \% \\
\uparrow \mathrm{T}_{\max } \text { by } 1.12-1.25 \mathrm{~h}\end{array}$ \\
\hline $\begin{array}{l}\text { Additional PDE } \\
\text { inhibition }\end{array}$ & $\mathrm{PDE}_{1}, \mathrm{PDE}_{6}$ & $\mathrm{PDE}_{1}, \mathrm{PDE}_{6}$ & $\mathrm{PDE}_{11}$ & - \\
\hline
\end{tabular}

Cmax = peak concentration CYP = cytochrome P450; Tmax = time to peak concentration .

Huang et al. [30] reported that each PDE-5 inhibitor undergoes metabolism predominantly through the hepatic isoenzyme cytochrome P450 (CYP) 3A4 pathway. Minor pathways include CYP2C9 for sildenafil, CYP3A5 and CYP2C for vardenafil and CYP2C for avanafil. Of these four pharmaceuticals, only tadalafil produces human metabolites that are not pharmacologically active. Sildenafil predominantly metabolises into an Ndesmethyl metabolite that contributes to approximately $20 \%$ of the parent molecule total pharmacological activity [35]. Vardenafil and avanafil produce active metabolites that contribute 7\% [36] and 4\% [37] of the real pharmacological action. All the PDE-5 inhibitors mainly excrete as metabolic by-products in the faeces and to a reduced amount in the urine.

Thanks to their different features, some PDE-5 inhibitors can be used in many clinical treatments and not only for erectile dysfunction treatments. For example, the national medicines agencies approved tadalafil for: (i) the treatment of lower urinary tract symptoms (LUTS); (ii) secondary to benign prostatic hyperplasia (BPH); and (iii) for the treatment of pulmonary arterial hypertension (PAH), a condition of increased blood pressure within the arteries of the lungs [34].

Sildenafil is approved for PAH treatment because it inhibits the PDE-5 in the pulmonary blood vessels and promotes the vasodilator action of nitric oxide by maintaining high cGMP levels [35].

In addition, researchers performing mice models with Alzheimer's disease proved that PDE-5 inhibitors can effectively promote the cGMP-mediated processes involved in consolidating information in memory and countering the neurodegenerative mechanisms typical of Alzheimer's disease [38].

Schnetzler et al. [39] estimated that about 6 million men in Europe could avoid the healthcare system to get PDE-5 medicines themselves. Market globalisation and the Internet are offering new scenarios and creating unknown risks for public health due to the growing attitude to buy drugs from the illegal market and online shops, exposing in this way more and more persons to the hazards due to the intake of illicit and counterfeit 
drugs [40]. Authorities developed specific legislative rules, particularly the European Directive 2011/62/UE, to avoid the trade of falsified medicinal products through the permitted supply chain. This Directive also normalises the Internet market of legal medicines by specifying that legal online pharmacies are obligated to exhibit a "common logo" on each page of the website dedicated to drugs sale [41,42]. An exciting and recent study [43] listed 80 new sexual performance enhancers detected illegally in the market that mimics the approved PDE-5 inhibitors.

\section{Content of PDE-5 Inhibitors in WWTPs and STPs}

Together with many other pharmaceutical products, these substances, once eliminated in faeces and urine, are transported through sewers to municipal wastewater treatment plants. Here, the parent substances and their metabolites are treated in biological reactors, which can only partially degrade them while triggering other transformation processes. They also often undergo accumulation processes before being discharged into the receiving water bodies. For this reason, investigations about the residues of these pharmaceuticals in the environment are essential to proceed with their removal. The first approach consists of determining the PDE-5 inhibitors' content in untreated wastewater samples taken at the entry into WWTPs. Despite the low or very low solubility in water and the positive values of the partition coefficients $(\log \mathrm{P})$, these products can arrive at municipal wastewater treatment plants adsorbed on the solid organic materials or dispersed in the liquid mass. Their lipophilicity favours their transport.

Research performed in eight WWTPs serving the catchment inside the towns of Bristol, Brussels, Castellón, Copenhagen, Milan, Oslo, Utrecht and Zurich [44] showed the presence of sildenafil and its two human urinary metabolites, desmethyl- and desethyl-sildenafil with amounts up to $60 \mathrm{ng} \mathrm{L}^{-1}$. They did not detect tadalafil and vardenafil in appreciable concentrations. The authors transformed the concentrations found in the collected samples to normalised loads and estimated the possible intake of sildenafil as amounts backcalculated from these loads. Moreover, they gathered the national prescription data from five countries in the form of the number of prescribed daily doses and transformed them into predicted loads for assessment. In Utrecht and Brussels, prescription data could only partially clarify the total quantity determined in wastewater.

In contrast, in Bristol, Milan and Oslo, the authors found that drug amounts in wastewater were lower than predicted from the prescription data. These studies illustrate the theoretical capacity of performed investigations to assess the use of imitating fraudulent medication and criminal online sales. Other researchers in Tarragona (Spain) and Germany determined the occurrence of these pharmaceuticals in WWTP influent and effluent water and sewage sludge [15] to evaluate the removal efficiency of the treatment systems and the possible influence of STPs on the pollution of the aquatic systems.

Sildenafil was the principal drug in all investigated water and sewage samples at a few ng $\mathrm{L}^{-1}$ and $\mathrm{ng} \mathrm{g}^{-1}$ range, respectively. Tadalafil was not identified or below the limit of detection (LOD) in effluent water collected in Spain but was revealed in sewage sludge (12 $\mathrm{ng} \mathrm{g}^{-1}$-LOD). Vardenafil was detected only in one sludge sample and between $5 \mathrm{ng} \mathrm{g}^{-1}$ and the LOD value in effluent water. The higher elimination efficiency of the STP in Tarragona (Spain) was $68 \%, 69 \%$ and $80 \%$ for sildenafil, tadalafil and vardenafil, respectively.

The monitoring evidenced the maximum concentrations for all drugs during the summer, probably due to the touristic fluxes (Figure 2, from [15]). 

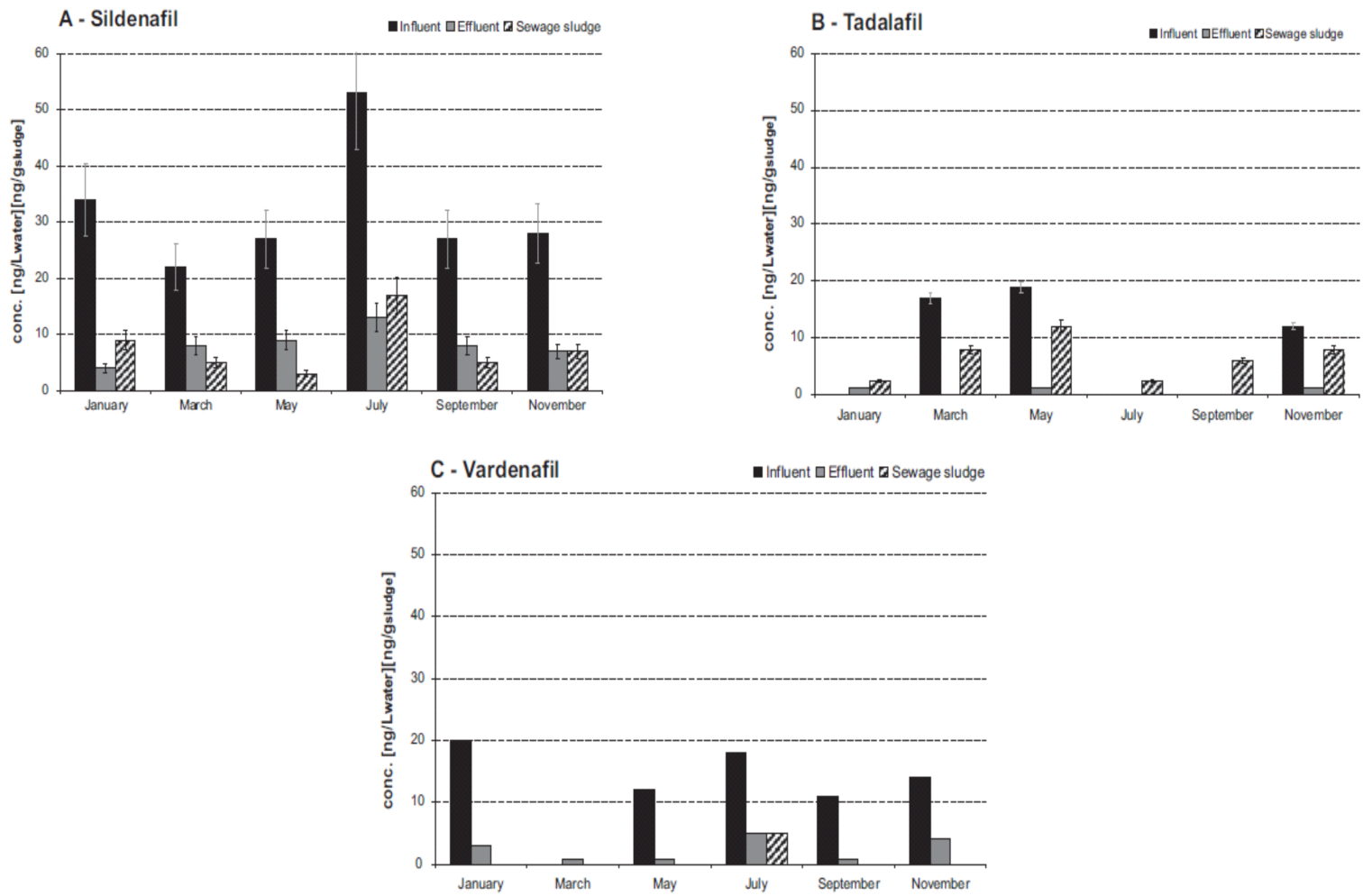

Figure 2. Amounts of sildenafil, tadalafil and vardenafil in influent and effluent wastewater and sludge samples collected from the STP Tarragona (Spain) [15]. Reprinted with permission from ref. [15]. Copyright 2021 Elsevier.

Studies conducted in several German STPs revealed that: (i) sildenafil was constantly in greater quantity (except in the case of Wiesbaden, where tadalafil was the most copious); (ii) sildenafil was detected in $100 \%$ of samples at concentrations ranging 6 to $18 \mathrm{ng} \mathrm{L}^{-1}$. The highest level of $18 \mathrm{ng} \mathrm{L}^{-1}$ was determined in the STP effluent from Bad Homburg, while the lowest amount of $6 \mathrm{ng} \mathrm{L}^{-1}$ remained in samples from Darmstadt. In general, there were no significant differences in sildenafil levels found in Spanish and German samples (Figure 3).

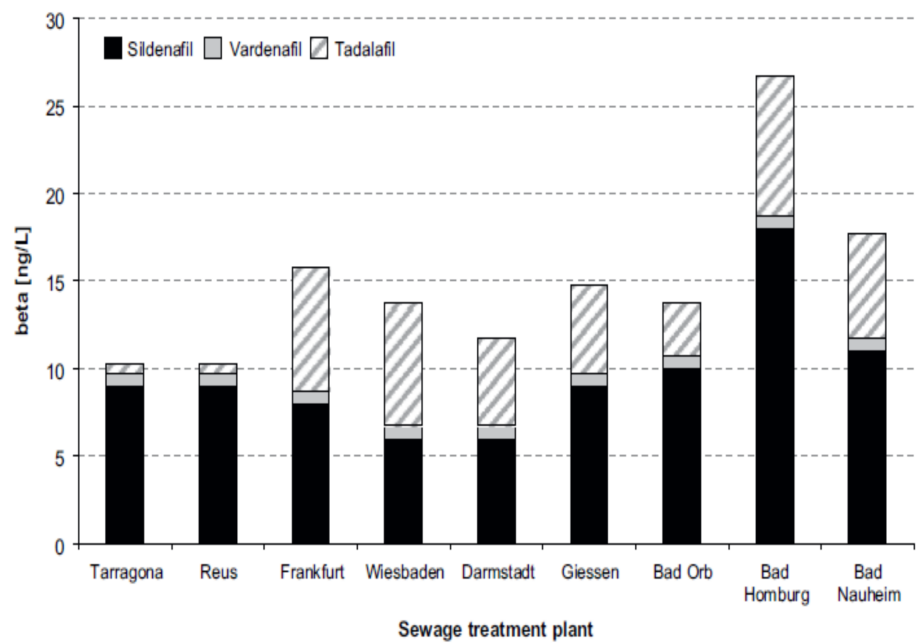

Figure 3. Amounts of drugs found in the STP effluent samples grabbed from Germany and Spain [15]. Reprinted with permission from ref. [15]. Copyright 2021 Elsevier.

Similar quantities of these drugs were also detected by Schroeder et al. in a fitness centre discharge in Germany [45] and by Papageorgiou et al. in WWTPs in Volos, Greece [46]. 
Beyond the levels found for these substances, it is crucial to consider that the hazard to the environment may derive from their transformation compounds, as described by Temussi et al. [47] and Eichhorn et al. [48].

\section{Removal Treatments}

The absence of guidelines has permitted the discharge of significant amounts of pharmaceuticals in the environment even because municipalities usually do not adopt WWTPs designed to remove these kinds of pollutants [49-52]. Unfortunately, there are no reference limits for most of these substances [53,54].

The effective removal of these compounds from wastewater before discharge into the water bodies is an emerging issue [55], and specific tertiary treatments could be indispensable.

There are different methods able to remove several emerging contaminants such as photolysis, biological degradation, filtration on carbonised materials [56,57], catalytic use of green-synthesised copper nanoparticles ( $\mathrm{Cu}$ NPs) [58] and adsorption on activated carbon [59].

\subsection{Advanced Oxidation Treatment}

It is easy to think that, due to their affinity for organic material, these products remain more in sewage sludge than in wastewater. But it is also true that the release into liquid effluents could be a constant. Ordinary sewage management does not eliminate these substances from the wastewater stream and consequently releases them into the receiving body of water [60]. Once they reach the aquatic systems, a combination of different processes governs their fate. Photochemical reactions are accounted as an essential process in the natural reduction of organic micropollutants [61].

However, it is essential to remember that the contaminant must be removed entirely, including its transformation into by-products and derivatives eventually formed during the decontamination stage.

Chlorination is by far the most adopted method in the disinfection stage in WWTPs. Wastewater is frequently added with chlorine as a sodium hypochlorite solution. However, the mixture $\mathrm{HOCl} / \mathrm{OCl}^{-}$, recognised as free available chlorine, is a potent non-specific oxidant that promotes transformation reactions of many micro-pollutants. As a result, chlorinated and oxidised by-products are usually obtained, which could be more toxic than the parent substances [62].

Temussi et al. [47] report remarkable results: drug chlorination experiments were performed on sildenafil and tadalafil, simulating conditions of a characteristic wastewater management procedure. The main transformation compounds were isolated and fully characterised. Sildenafil showed a high reactivity by hypochlorite addition and was completely mineralised in $1 \mathrm{~h}$. The reaction mixtures were treated with thiosulfate to remove the hypochlorite excess and then extracted with ethyl acetate. No appreciable variations were detected in the experiments, and three main by-products were isolated by chromatographic separation and identified by spectroscopic analyses (S1-S3) (Figure 4).

Tadalafil (T) was converted by hypochlorite addition. Indeed, the researchers observed the compounds T1-T3 (Figure 5). These substances were produced by cleaving the bond between nitrogen and benzylic carbon, followed by carbon oxidation. Contemporarily, the chlorination reaction of the aromatic ring and indolic nitrogen occurred for compounds T1 and T2 [63]. Spectroscopic features were essential to elucidate the structure of the compounds. 


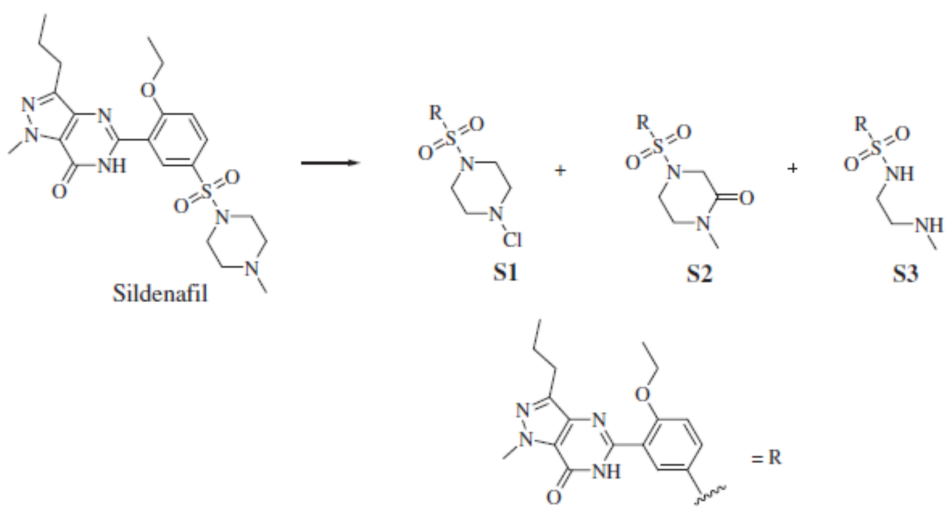

Figure 4. Sildenafil and its chlorination products [47]. It is reproduced with the permission of Elsevier. Reprinted with permission from ref. [47]. Copyright 2021 Elsevier.

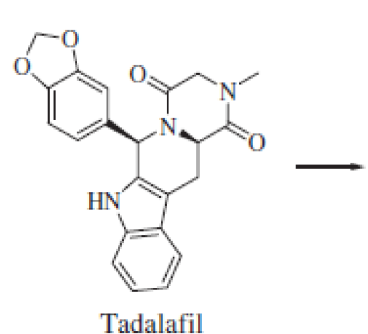

Tadalafil

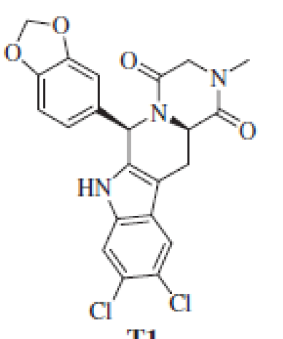

T1

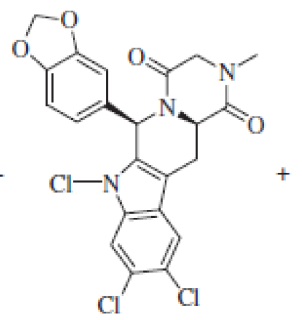

T2

Figure 5. Tadalafil and its chlorination products [47]. It is reproduced with the permission of Elsevier. Reprinted with permission from ref. [47]. Copyright 2021 Elsevier.

\subsection{Biological Degradation}

De Felice et al. [64] studied the genetic outline of the microbial community emerging in a sildenafil-polluted aquatic environment. They isolated the $16 \mathrm{~S}$ and $18 \mathrm{~S}$ rRNA genes for bacteria and fungi, amplified by polymerase chain reaction (PCR) and separated using the denaturing gradient gel electrophoresis (DGGE) technique. Analysis of DGGE data indicated that the microbial composition changed with numerous major species in the last period of the experiment. This result suggests that great variety in microorganisms might be necessary for the effective biodegradation of pollutants. When more microbial species with different physiological capabilities are involved, many diverse organic pollutants might be degraded. In general, the use of mixed microbial consortia to remediate polluted sites is encouraged.

A few years later, Grossberger et al. [65] reported, in a study of agricultural soils irrigated with treated wastewater, that sildenafil was recalcitrant and accumulated in the surface layer. Sildenafil, not found in the soil before irrigation, was identified after irrigation. An increase of its concentration with subsequent irrigations occurs, suggesting an accumulation of the chemical in the top layer, which is noteworthy. This effect could follow the ampholytic characteristic of sildenafil, which does not ionise at environmentally relevant $\mathrm{pH}$ levels.

The final considerations from the literature results are that the soil composition, the structure of the contaminant molecule and an adequate microbial community influence the degradation of these kinds of pollutants.

\subsection{Adsorption on Activated Carbon}

Delgado et al. [59] reported the efficiency of eliminating sildenafil citrate from water using powdered activated carbon. Having obtained a removal efficiency greater than $85 \%$, they promoted the use of activated carbon as an effective tool for removing these kinds of recalcitrant emerging pollutants. 


\section{Toxicity Assessment}

De Felice et al. [64] tested the biological degradation and the possible toxicity of microbial transformation substances of sildenafil in several living models such as Daphnia magna and Pseudokirchneriella subcapitata microalgae and human HepG2 cells to evaluate the mitochondrial activity.

Toxicological tests showed that only the initial sildenafil concentration $\left(400 \mathrm{mg} \mathrm{L}^{-1}\right)$ was toxic for D. magna and caused a decrease of cellular viability by $50 \%$ for HepG2 cells (Figure 6A,B, respectively). These assays revealed the absence of toxicity for the biotransformation products (Figure 6C).

Temussi et al. [47] carried out aquatic acute and chronic toxicity tests with Brachionus calyciflorus and Ceriodaphnia dubia and mutagenesis and genotoxicity analyses for some bacterial strains to evaluate the adverse environmental effects of parent compounds and transformation products obtained simulating the chlorination stage of a WWTP.

The authors selected the freshwater rotifer B. calyciflorus and the microcrustacean C. dubia as demonstrative aquatic organisms because they have an extensive geographic distribution and substantially impact water's critical ecological processes. Furthermore, the authors performed mutagenesis and genotoxicity assays using the Ames test on Salmonella typhimurium and the SOS Chromotest on Escherichia coli PQ37 to detect the induction of point mutations of the SOS DNA repair system. The results of the acute toxicity tests are in Table 2.

Table 2. Acute $\mathrm{LC}_{50}$ values in $\mathrm{mg} \mathrm{L}^{-1}$ with confidence limits (95\% probability) of sildenafil and tadalafil and their respective derivatives S1 and T1 [47]. Reprinted with permission from ref. [47]. Copyright 2021 Elsevier.

\begin{tabular}{ccc}
\hline & B. calyciflorus & C. dubia \\
\hline Sildenafil citrate & 42.74 & 5.74 \\
& $(34.32-53.21)$ & $(3.08-10.71)$ \\
\hline $\mathrm{S}_{1}$ & 19.82 & 6.60 \\
& $(17.51-22.43)$ & NE up to 20 \\
\hline Tadalafil & NE up to 20 & NE up to 20 \\
\hline $\mathrm{T}_{1}$ & NE up to 20 & \\
\hline
\end{tabular}

NE: no effect.

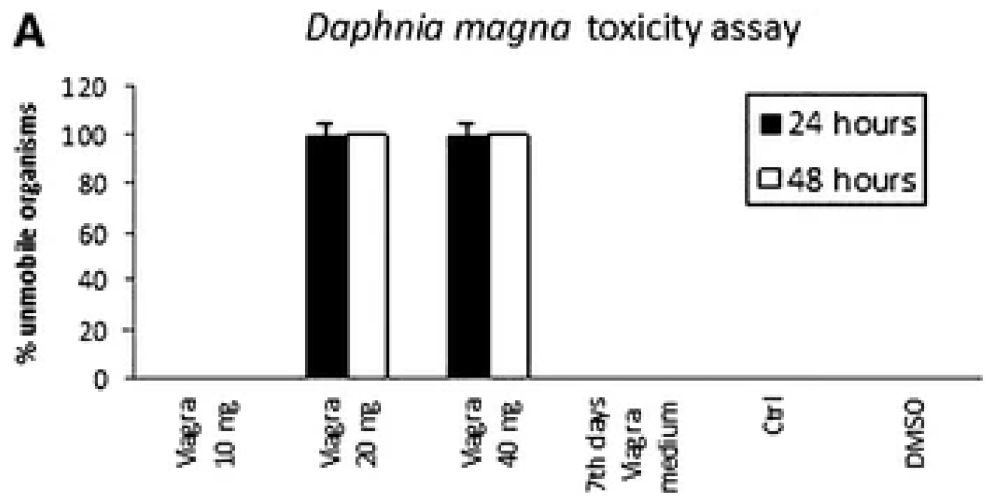

Figure 6. Cont. 

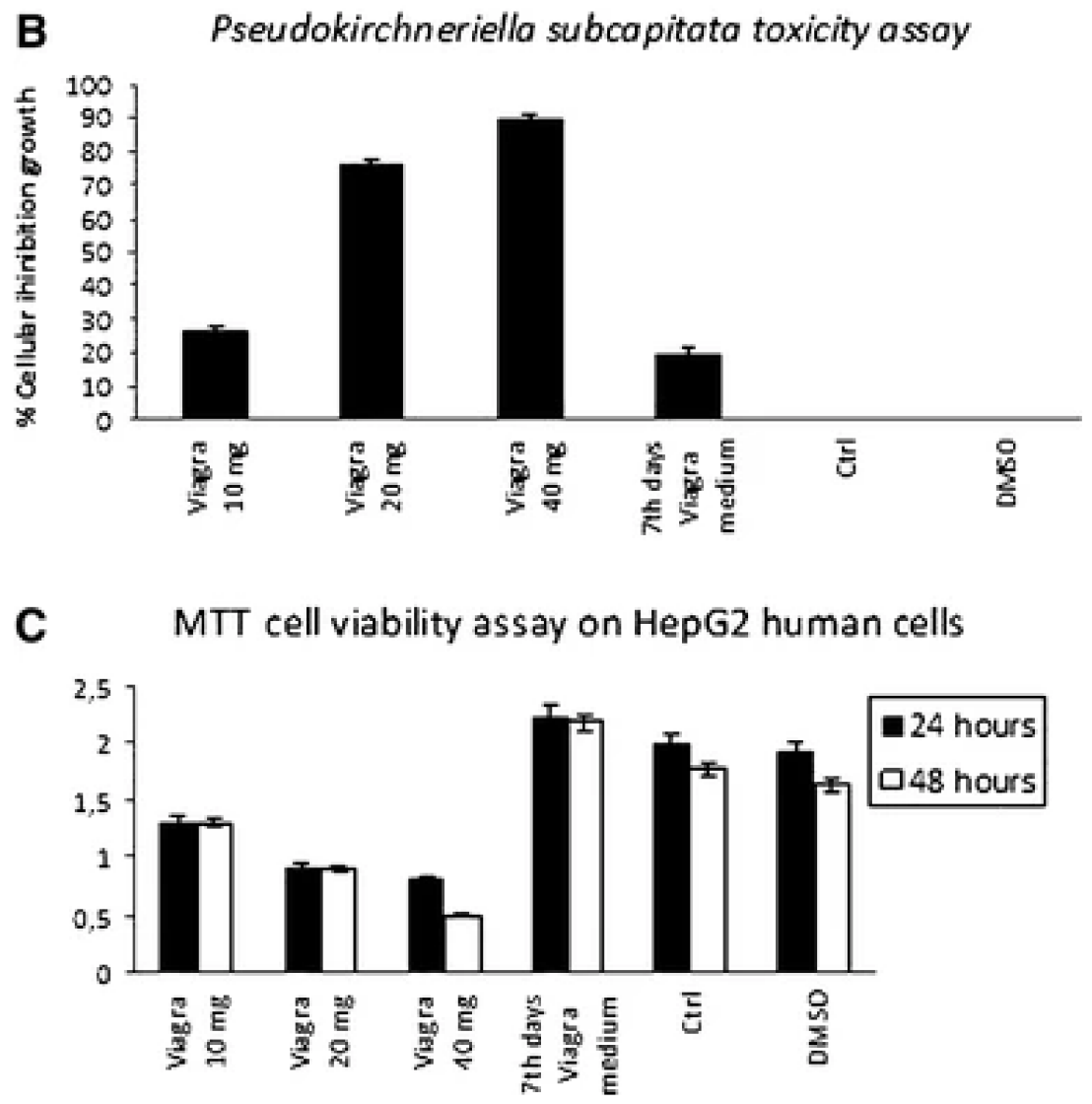

Figure 6. (A) Viability of Daphnia magna after 24 and $48 \mathrm{~h}$ incubation with sildenafil citrate (mean \pm SD). (B) Viability of Pseudokirchneriella subcapitata after $24 \mathrm{~h}$ incubation with sildenafil citrate (mean \pm SD). (C) Viability of HepG2 cells after $24 \mathrm{~h}$ incubation with sildenafil citrate (mean \pm SD) [64]. Reprinted with permission from ref. [64]. Copyright 2021 Springer Nature.

Chemical analysis revealed that the actual number of drugs diverged from the nominal one by less than $10 \%$, so he researchers calculated the $\mathrm{EC}_{50}$ values using the nominal concentrations.

Tadalafil did not exhibit any acute consequence on both organisms up to the highest concentration tested $\left(20 \mathrm{mg} \mathrm{L}^{-1}\right)$. Sildenafil did not display any effect up to the highest concentration tested $\left(10 \mathrm{mg} \mathrm{L}^{-1}\right)$ for $B$. calyciflorus, while it showed an $\mathrm{EC}_{50}$ value of $0.64 \mathrm{mg} \mathrm{L}^{-1}$ for C. dubia. Chlorine derivatives of both drugs evidenced a different behaviour: the compound S1 showed long-term effects for both test organisms, while the product T1 only for crustaceans.

Literature on the additional biological effects of drugs such as mutagenesis and genotoxicity is also available [66-68]. The risk associated with small quantities of drugs is frequently due to their mutagenic and genotoxic potential already examined on mammalian cell lines or bacterial models. Sildenafil and tadalafil and the respective derivatives could not induce an SOS activation response, while the results of the Ames test were fascinating (Table 3). Tadalafil expressed a significant mutagenic activity (maximum $\mathrm{MR}=18.4$ ) in TA98 with a positive range of concentrations from 0.625 to $10 \mu \mathrm{g} \mathrm{mL}^{-1}$, and it was positive also in TA100 (2.5-10 $\left.\mu \mathrm{g} \mathrm{mL}^{-1}\right)$. The derivative T1 had a mutagenic potential $\left(2.5-10 \mu \mathrm{g} \mathrm{mL}^{-1}\right)$ for TA98, but it was negative for TA100. Rocco et al. [69] studied the possible genetic damage of sildenafil through a Comet assay, diffusion assay and RAPD-PCR for the erythrocytes of Danio rerio. They found statistically significant genotoxicity. 
Table 3. Ames test results for parent compounds, chlorine derivatives and positive and negative controls. In bold are the positive MRs [47]. Reprinted with permission from ref. [47]. Copyright 2021 Elsevier.

\begin{tabular}{|c|c|c|c|c|c|c|}
\hline \multirow[t]{3}{*}{ Compounds } & \multicolumn{6}{|c|}{ Ames Test } \\
\hline & \multicolumn{2}{|l|}{ TA98 } & \multicolumn{3}{|c|}{ TA100 } & \multirow[b]{2}{*}{$\mathrm{MR}^{\mathrm{a}}$} \\
\hline & $\begin{array}{l}\text { Concentration } \\
\left(\mu \mathrm{g} \mathrm{mL}^{-1}\right)\end{array}$ & $\begin{array}{c}\text { Mean } \\
\text { Revertants/Plate } \\
( \pm S D)\end{array}$ & $\mathrm{MR}^{\mathrm{a}}$ & $\begin{array}{l}\text { Concentration } \\
\left(\mu g \mathrm{~mL}^{-1}\right)\end{array}$ & $\begin{array}{c}\text { Mean } \\
\text { Revertants/Plate } \\
( \pm S D)\end{array}$ & \\
\hline \multirow{4}{*}{$\begin{array}{l}\text { Negative Control2- } \\
\text { Nitrofluoren }\end{array}$} & - & $29.6 \pm 2.7$ & - & & \multirow{4}{*}{$\begin{array}{c}190.1 \pm 47.2 \\
-\end{array}$} & \multirow{4}{*}{-} \\
\hline & 2.5 & $61.0 \pm 5.7$ & 2.1 & - & & \\
\hline & 5 & $83.2 \pm 11.3$ & 2.8 & - & & \\
\hline & 10 & $178.0 \pm 15.0$ & 6 & & & \\
\hline \multirow{3}{*}{ Sodium azide } & \multirow{3}{*}{-} & \multirow{3}{*}{-} & \multirow{3}{*}{-} & 5 & $488.0 \pm 96.9$ & 2.6 \\
\hline & & & & 10 & $794.7 \pm 90.9$ & 4.2 \\
\hline & & & & 20 & $1153.3 \pm 239.8$ & 6.1 \\
\hline \multirow{5}{*}{ Sildenafil citrate } & 0.625 & $46.7 \pm 13.1$ & 1.6 & 0.625 & $161.0 \pm 18.7$ & 0.8 \\
\hline & 1.25 & $48.7 \pm 5.1$ & 1.6 & 1.25 & $164.6 \pm 8.7$ & 0.9 \\
\hline & 2.5 & $72.0 \pm 11.3$ & 2.4 & 2.5 & $190.6 \pm 12.6$ & 1 \\
\hline & 5 & $93.0 \pm 4.4$ & 3.1 & 5 & $198.3 \pm 24.0$ & 1 \\
\hline & 10 & $170.7 \pm 32.0$ & 5.8 & 10 & $220.0 \pm 46.8$ & 1.2 \\
\hline \multirow{6}{*}{ S1 } & 0.3125 & $27.8 \pm 3.2$ & 0.9 & 0.3125 & $241.1 \pm 27.5$ & 1.3 \\
\hline & 0.625 & $37.6 \pm 4.7$ & 1.3 & 0.625 & $291.1 \pm 21.6$ & 1.5 \\
\hline & 1.25 & $37.3 \pm 11.6$ & 1.3 & 1.25 & $303.1 \pm 44.7$ & 1.6 \\
\hline & 2.5 & $53.6 \pm 9.0$ & 1.8 & 2.5 & $376.6 \pm 45.3$ & 2 \\
\hline & 5 & $64.7 \pm 20.2$ & 2.2 & 5 & $405.1 \pm 82.5$ & 2.1 \\
\hline & 10 & $112.4 \pm 41.5$ & 3.8 & 10 & $444.2 \pm 83.2$ & 2.3 \\
\hline \multirow{6}{*}{ Tadalafil } & 0.3125 & $49.5 \pm 7.7$ & 1.7 & 0.3125 & $298.5 \pm 38.7$ & 1.6 \\
\hline & 0.625 & $67.2 \pm 12.2$ & 2.3 & 0.625 & $318.6 \pm 65.2$ & 1.7 \\
\hline & 1.25 & $149.3 \pm 33.2$ & 5 & 1.25 & $325.6 \pm 94.4$ & 1.7 \\
\hline & 2.5 & $223.0 \pm 54.8$ & 7.5 & 2.5 & $425.3 \pm 80.9$ & 2.2 \\
\hline & 5 & $337.3 \pm 32.3$ & 11.4 & 5 & $556.0 \pm 41.7$ & 2.9 \\
\hline & 10 & $544.0 \pm 92.1$ & 18.4 & 10 & $880.0 \pm 237.6$ & 4.6 \\
\hline \multirow{5}{*}{$\mathrm{T} 1$} & 0.625 & $43.6 \pm 11.9$ & 1.5 & 0.625 & $286.0 \pm 14.1$ & 1.5 \\
\hline & 1.25 & $43.5 \pm 14.0$ & 1.5 & 1.25 & $310.7 \pm 43.9$ & 1.6 \\
\hline & 2.5 & $85.4 \pm 19.2$ & 2.9 & 2.5 & $322.7 \pm 28.4$ & 1.7 \\
\hline & 5 & $221.8 \pm 57.2$ & 7.5 & 5 & $288.0 \pm 40.6$ & 1.5 \\
\hline & 10 & $391.2 \pm 69.4$ & 13.2 & 10 & $410.7 \pm 70.0$ & 2.2 \\
\hline
\end{tabular}

$\pm \mathrm{SD}$ = standard deviation obtained from three independent experiments. ${ }^{\text {a }} \mathrm{MR}$ (mutagenic ratio): number of revertants/plate compared to the negative control.

\section{Impact on the Aquatic Organisms}

To better understand the mechanisms that allow marine invertebrates to survive and reproduce in contaminated and changing habitats, researchers investigated the effect of some drugs, including sildenafil, on aquatic organisms. In particular, Zanuri et al. [70] studied Asterias rubens, Psammechinus miliaris and Arenicola marina (Polychaeta), essential components of marine benthos. They investigated the effects of exposure time and dosage of diclofenac, ibuprofen and sildenafil citrate on sperm motility and subsequent fertilisation. Diclofenac concentrations $\geq 0.1 \mu \mathrm{g} \mathrm{L}{ }^{-1}$ caused a reduction in motility for all species observed. Exposure to $\geq 1.0 \mu \mathrm{g} \mathrm{L}{ }^{-1}$ ibuprofen affected only P. miliaris gametes and A. marina fertilisation. Only the spermatozoa of $A$. rubens and $P$. miliaris exposed to sildenafil citrate at concentrations $\geq 18$ and $\geq 50 \mathrm{ng} \mathrm{L}^{-1}$, respectively, showed higher percentage motility and a significant increase in fertilisation [70] (Figure 7; Table 4). Sildenafil citrate was non-toxic in all cases.

Su et al. [71] confirmed the influence of PDE-5 inhibitors on the sperm motility increase for aquatic species that studied this effect on the sperm of sea urchin. The data are consistent 
with the hypothesis that suPDE-5 regulates cyclic guanine monophosphate (cGMP) levels in sperm, modulating sperm motility.

Rocco et al. [69] analysed the genotoxic damage caused by sildenafil citrate, a vasodilator, gemfibrozil, and atorvastatin, two regulators of the lipids' hematic level, for the teleost fish Danio rerio (Zebrafish). This species is a bio-indicator used for genetic toxicology studies (Table 5) [72-74]. The pharmacological agents chosen by the authors are mainly present in high concentrations in Italian-treated wastewater.
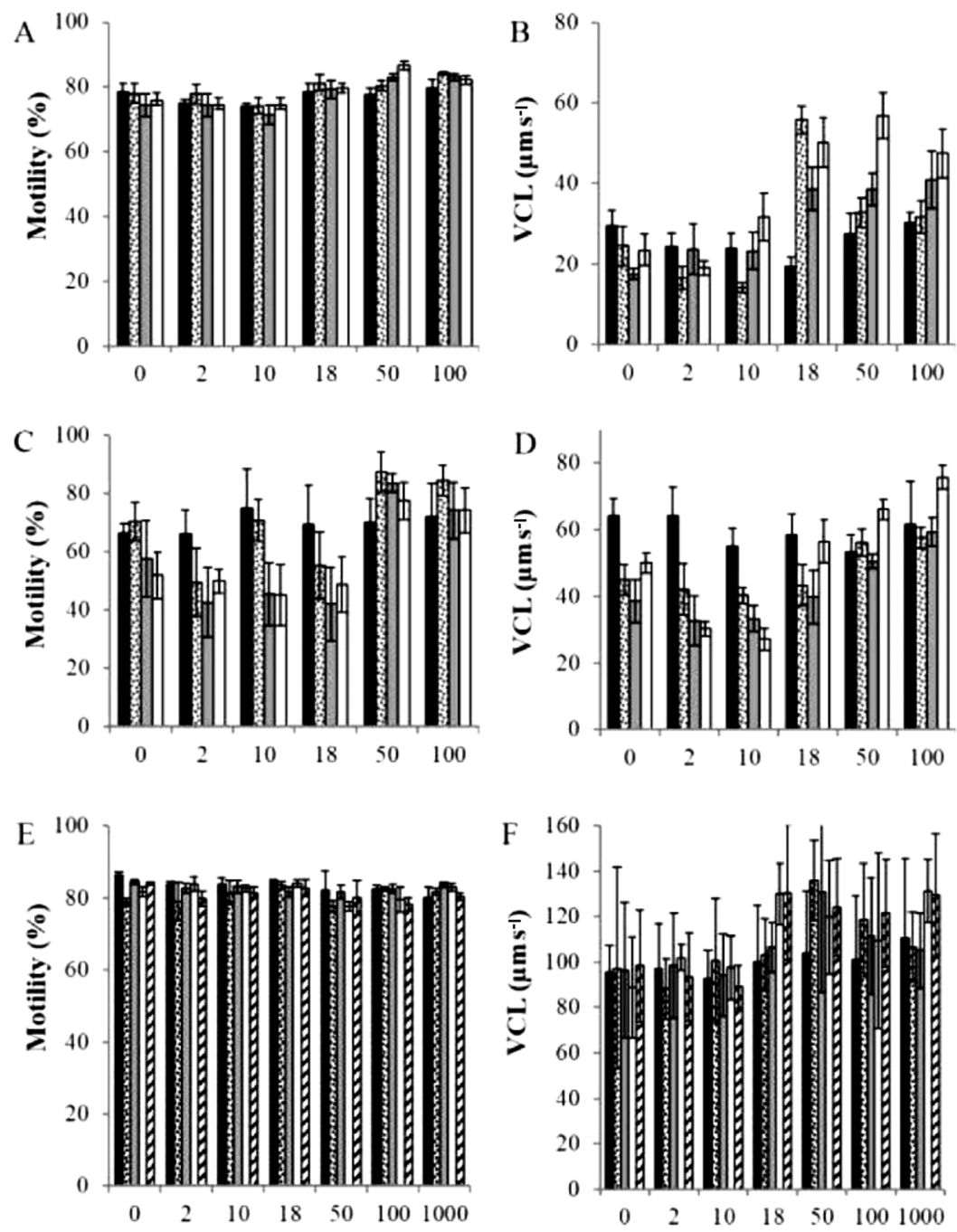

Legenda:

$=0 \mathrm{~min}$; 圈 = $20 \mathrm{~min}(A r, P m), 30 \mathrm{~min}(A m)$;

$=40 \min (A r, P m), 60 \min (A m)$; $60 \min (A r, P m), 90 \min (A m) ; \mathscr{V}=120 \mathrm{~min}$.

Figure 7. Percentage of sperm motility $(\mathbf{A}, \mathbf{C}, \mathbf{E})$ and curvilinear velocity (VCL) $(\mathbf{B}, \mathbf{D}, \mathbf{F})$ of sperm of Asterias rubens (A,B), Psammechinus miliaris (C,D), and Arenicola marina (E,F) after exposure to sildenafil citrate for set periods [70]. Reprinted with permission from ref. [70]. Copyright 2021 Elsevier.

Once again, Comet and diffusion assays and RAPD-PCR are the resources used to evaluate the genotoxicity of the drugs [69]. The obtained data showed a statistically significant loss of DNA integrity after 35 days of exposure to sildenafil citrate, after five days to atorvastatin and after one week of exposure to gemfibrozil. In addition, the fishes treated with sildenafil citrate at the concentration of $26.25 \mathrm{ng} \mathrm{L}^{-1}$ for 5 and 7 days exhibited a percentage of apoptotic cells similar to the control animals. However, the treatment extended to 35 days showed a significant increase of apoptotic cells $(7.7 \%)$, demonstrating that this pharmacological agent induces genotoxic damage over time. 
These data could suggest that there is no human health risk for exposure to sildenafil and tadalafil. However, they require great attention since this kind of contamination is present in each aquatic system investigated.

Table 4. No-observed-effects (NOEC) or lowest-observed-effects concentration (LOEC), half-minimal effective concentration $\left(\mathrm{EC}_{50}\right)$, and toxicity substance classification for Asterias rubens, Psammechinus miliaris and Arenicola marina. Toxicity classification is from EU Directive 93/67/EEC: $\mathrm{EC}_{50}\left(\mu \mathrm{g} \mathrm{L}^{-1}\right)>100,000=$ non-toxic; $10,000-100,000=$ harmful; $1000-10,000=$ toxic; $<100-1000=$ very toxic; and $<100=$ extremely toxic. $\mathrm{N} / \mathrm{A}=$ not applicable as an $\mathrm{EC}_{50}$ could not be calculated and is therefore deemed non-toxic [70]. Reprinted with permission from ref. [70]. Copyright 2021 Elsevier.

\begin{tabular}{|c|c|c|c|c|c|}
\hline Species & Test & Pharmaceutical & $\begin{array}{c}\text { NOEC or } \\
\text { LOEC }\left(\mu \mathrm{g} \mathrm{L}^{-1}\right)\end{array}$ & $\mathrm{EC}_{50}\left(\mu \mathrm{g} \mathrm{L}^{-1}\right)$ & Classification \\
\hline \multirow{4}{*}{ Asterias rubens } & Sperm motility & Sildenafil citrate & $\mathrm{NOEC}=0.18$ & $60 \min =2.25 \times 10^{12}$ & Non-toxic \\
\hline & $\begin{array}{l}\text { Fertilisation: sperm } \\
\text { pre-incubation }\end{array}$ & Sildenafil citrate & $\mathrm{NOEC}=0.010$ & $60 \min =7.15 \times 10^{13}$ & Non-toxic \\
\hline & $\begin{array}{c}\text { Fertilisation: oocyte } \\
\text { pre-incubation }\end{array}$ & Sildenafil citrate & $\mathrm{NOEC}=0.10$ & $\mathrm{~N} / \mathrm{A}$ & $\mathrm{N} / \mathrm{A}$ \\
\hline & $\begin{array}{l}\text { Fertilisation: sperm } \\
\text { and oocyte } \\
\text { pre-incubation }\end{array}$ & Sildenafil citrate & $\mathrm{NOEC}=0.01$ & $60 \mathrm{~min}=2.37 \times 10^{12}$ & Non-toxic \\
\hline \multirow{4}{*}{$\begin{array}{l}\text { Psammechinus } \\
\text { miliaris }\end{array}$} & Sperm motility & $\begin{array}{c}\text { Diclofenac } \\
\text { Ibuprofen } \\
\text { Sildenafil citrate }\end{array}$ & $\begin{array}{c}\mathrm{NOEC}=0.01 \\
\mathrm{NOEC}=0.1 \\
\mathrm{NOEC}=0.018\end{array}$ & $\begin{array}{c}60 \min =378.22 \\
60 \min =845.98 \\
60 \min =7.23 \times 10^{10}\end{array}$ & $\begin{array}{l}\text { Very toxic } \\
\text { Very toxic } \\
\text { Non-toxic }\end{array}$ \\
\hline & $\begin{array}{c}\text { Fertilisation: sperm } \\
\text { pre-incubation }\end{array}$ & Sildenafil citrate & $\mathrm{NOEC}=0.10$ & $60 \min =6.241 \times 10^{10}$ & Non-toxic \\
\hline & $\begin{array}{c}\text { Fertilisation: oocyte } \\
\text { pre-incubation }\end{array}$ & Sildenafil citrate & $\mathrm{NOEC}=0.01$ & $\mathrm{~N} / \mathrm{A}$ & $\mathrm{N} / \mathrm{A}$ \\
\hline & $\begin{array}{l}\text { Fertilisation: sperm } \\
\text { and oocyte } \\
\text { pre-incubation }\end{array}$ & $\begin{array}{c}\text { Diclofenac } \\
\text { Ibuprofen } \\
\text { Sildenafil citrate }\end{array}$ & $\begin{array}{c}\mathrm{LOEC}=0.01 \\
\mathrm{NOEC}=0.10 \\
\mathrm{NOEC}=1.0\end{array}$ & $\begin{array}{c}60 \min =247.31 \\
60 \min =792.96 \\
\text { N } / A\end{array}$ & $\begin{array}{l}\text { Very toxic } \\
\text { Very toxic } \\
\text { N/A }\end{array}$ \\
\hline \multirow{4}{*}{ Arenicola marina } & Sperm motility & Sildenafil citrate & $\mathrm{NOEC}=1.0$ & $\mathrm{~N} / \mathrm{A}$ & $\mathrm{N} / \mathrm{A}$ \\
\hline & $\begin{array}{l}\text { Fertilisation: sperm } \\
\text { pre-incubation }\end{array}$ & $\begin{array}{c}\text { Diclofenac } \\
\text { Ibuprofen } \\
\text { Sildenafil citrate }\end{array}$ & $\begin{array}{l}\mathrm{NOEC}=1.00 \\
\mathrm{NOEC}=0.10 \\
\mathrm{NOEC}=1.0\end{array}$ & $\begin{array}{c}120 \min =565.53 \\
120 \min =3.24 \times 10^{9} \\
\text { N } / A\end{array}$ & $\begin{array}{l}\text { Very toxic } \\
\text { Non toxic } \\
\text { N/A }\end{array}$ \\
\hline & $\begin{array}{l}\text { Fertilisation: oocyte } \\
\text { pre-incubation }\end{array}$ & Sildenafil citrate & $\mathrm{NOEC}=1.00$ & $\mathrm{~N} / \mathrm{A}$ & $\mathrm{N} / \mathrm{A}$ \\
\hline & $\begin{array}{l}\text { Fertilisation: sperm } \\
\text { and oocyte } \\
\text { pre-incubation }\end{array}$ & Sildenafil citrate & $\mathrm{NOEC}=1.0$ & $\mathrm{~N} / \mathrm{A}$ & $\mathrm{N} / \mathrm{A}$ \\
\hline
\end{tabular}


Table 5. Experimental conditions of treatment and percentage of DNA in the tail and apoptotic cells in Danio rerio erythrocytes exposed to atorvastatin, gemfibrozil and sildenafil citrate with $p$-value $(*=5<0.05)$ [69]. Reprinted with permission from ref. [69]. Copyright 2021 John Wiley and Sons.

\begin{tabular}{|c|c|c|c|c|c|c|c|c|c|}
\hline \multirow[t]{2}{*}{$\begin{array}{l}\text { Pharmaceutical } \\
\text { Compound }\end{array}$} & \multirow[t]{2}{*}{$\begin{array}{l}\text { Mean Con- } \\
\text { centration } \\
\mathrm{ng} \mathrm{L}^{-1}\end{array}$} & \multirow[t]{2}{*}{$\begin{array}{l}\text { Number of } \\
\text { Specimens } \\
\text { Examined }\end{array}$} & \multirow[t]{2}{*}{$\begin{array}{l}\text { Days } \\
\text { of } \\
\text { Treat- } \\
\text { ment }\end{array}$} & \multicolumn{2}{|c|}{$\begin{array}{c}\text { Tail DNA } \\
\text { Mean } \% \pm \text { SD }\end{array}$} & \multirow[t]{2}{*}{$\begin{array}{c}p \text {-Value } \\
\text { Tail } \\
\text { DNA }\end{array}$} & \multicolumn{2}{|c|}{$\begin{array}{l}\text { Apoptotic Cells } \\
\text { Mean } \% \pm \text { SD }\end{array}$} & \multirow[t]{2}{*}{$\begin{array}{l}p \text {-Value } \\
\text { Apoptotic } \\
\text { Cells }\end{array}$} \\
\hline & & & & NT & $\mathrm{T}$ & & NT & $\mathrm{T}$ & \\
\hline \multirow{3}{*}{ Atorvastatin } & \multirow{3}{*}{13} & \multirow{3}{*}{20} & 5 & $20.41 \pm 4.44$ & $50.47 \pm 9.19$ & $0.003 *$ & $1.0 \pm 0.21$ & $6.5 \pm 1.85$ & $0.003 *$ \\
\hline & & & 7 & $27.68 \pm 13.49$ & $40.81 \pm 16.34$ & 0.535 & $1.5 \pm 0.31$ & $5.7 \pm 1.78$ & 0.020 * \\
\hline & & & 14 & $19.96 \pm 4.99$ & $31.05 \pm 13.03$ & 0.426 & $1.2 \pm 0.34$ & $4.3 \pm 1.86$ & 0.101 \\
\hline \multirow{3}{*}{ Gemfibrozil } & \multirow{3}{*}{380} & \multirow{3}{*}{20} & 5 & $25.76 \pm 12.94$ & $55.12 \pm 7.42$ & $0.045^{*}$ & $6.9 \pm 0.22$ & $8.6 \pm 0.68$ & 0.017 * \\
\hline & & & 7 & $27.24 \pm 11.74$ & $60.67 \pm 11.78$ & 0.044 * & $5.7 \pm 0.84$ & $9.6 \pm 1.34$ & $0.013 *$ \\
\hline & & & 14 & $12.45 \pm 2.32$ & $18.47 \pm 2.78$ & 0.096 & $4.5 \pm 0.94$ & $5.7 \pm 0.75$ & 0.298 \\
\hline \multirow{6}{*}{$\begin{array}{l}\text { Sildenafil } \\
\text { citrate }\end{array}$} & \multirow{6}{*}{26.25} & \multirow{3}{*}{20} & 5 & $20.41 \pm 4.44$ & $25.79 \pm 10.13$ & 0.627 & $1.0 \pm 0.28$ & $1.8 \pm 0.42$ & 0.113 \\
\hline & & & 7 & $27.68 \pm 13.49$ & $34.00 \pm 8.19$ & 0.688 & $1.5 \pm 0.25$ & $2.5 \pm 1.45$ & 0.497 \\
\hline & & & 14 & $19.96 \pm 4.99$ & $29.93 \pm 18.02$ & 0.593 & $1.2 \pm 0.21$ & $2 \pm 0.56$ & 0.181 \\
\hline & & \multirow{2}{*}{22} & 21 & $36.56 \pm 13.33$ & $39.29 \pm 14.78$ & 0.890 & $4.9 \pm 0.25$ & $5.3 \pm 0.21$ & 0.220 \\
\hline & & & 28 & $15.87 \pm 5.08$ & $12.99 \pm 4.25$ & 0.663 & $1.4 \pm 0.25$ & $1.1 \pm 0.56$ & 0.625 \\
\hline & & 21 & 35 & $15.36 \pm 4.86$ & $49.15 \pm 16.67$ & 0.051 * & $1.3 \pm 0.23$ & $7.6 \pm 2.95$ & $0.033 *$ \\
\hline
\end{tabular}

$\mathrm{SD}$, standard deviation; NT, untreated; T, exposed to the compound indicated.

\section{Analytical Methods for PDE-5 Inhibitors Detection}

Several analytical methods are suitable to estimate the concentration of PDE-5 inhibitors: spectrophotometric methods [75-80], capillary electrophoretic methods [81], atomic emission and atomic absorption spectrometry methods [82] and chromatographic techniques (GC-LC-HPLC-UHPLC) coupled with different detectors, including mass spectrometers (MS) [83-87]. Only a few reports are available in the literature for the GC-MS use to analyse PDE-5 inhibitors, maybe due to the thermal instability of these compounds and their analogues and the difficulties in derivatising them with standard silylation reagents [88-91]. Liquid chromatography techniques, instead, seem to be more suitable for the analysis of PDE-5 inhibitors.

\subsection{Sample Preparation}

Sample preparation is an essential task in PDE-5 inhibitors detection. Since the concentrations of the target analytes in environmental samples are expected to be in the low ng L-1 range, an efficient sample preparation to extract the analytes from the respective matrix is required. For aqueous samples, solid-phase extraction (SPE) is widely used. Pressurised liquid extraction (PLE) has been successfully used for solid samples to determine pharmaceutical compounds in sewage sludge.

Solid-phase extraction (SPE) involved using a small amount of sorbent (commonly hundreds of $\mathrm{mg}$ ) in a cartridge or syringe barrel. After activation of the sorbent, a water sample of hundreds of $\mathrm{mL}$ was passed through the sorbent, which retained the analytes of interest (in this case, PPCPs) whereas the water was discarded. Then, the analytes retained in the sorbent were eluted using a few $\mathrm{mL}$ of organic solvent. This technique has some advantages, such as the minor investment in reagent and materials and rapidity.

\subsection{Spectrophotometric Methods}

Spectrophotometric methods are habitually used for the chemical analyses of pharmaceuticals, thanks to their versatility and cost-effectiveness. They can be successfully applied for pharmaceutical determinations, including the quality control of commercialised substances and pharmacodynamic investigations. Since most pharmaceutical compounds show several unsaturations and aromatic rings in their structure, one of the main ad- 
vantages of their analysis through spectrophotometric methods is the possibility of their determinations without preliminary derivatisation steps [92].

Ahmed et al. [80] developed a simple and accurate UV-spectrophotometric method to estimate vardenafil hydrochloride in pharmaceutical preparations and environmental wastewater samples. This compound exhibited the maximum absorption at a wavelength of $214 \mathrm{~nm}$ in distilled water. The proposed method was simple, straightforward and sensitive, providing $3.32 \mathrm{ng} \mathrm{mL}^{-1}$ and $10.96 \mathrm{ng} \mathrm{mL}^{-1}$ as LOD and LOQ values, respectively.

However, as sildenafil citrate is among the most widely used PDE-5 inhibitors, most research has focused on it. For example, Baokar et al. [93] validated a spectrophotometric method for detecting sildenafil in pharmaceutical formulation with good linearity in the range of 2 to $10 \mathrm{mg} \mathrm{mL}^{-1}$, using $228 \mathrm{~nm}$ as the wavelength of maximum absorption. This method also showed an excellent intra-day and inter-day precision and a recovery of 99-101\%.

Although the spectrophotometric analysis of these pharmaceuticals can be done quickly, conjugation with other compounds to increase sensitivity is reported in some methods, e.g., bromocresol purple (BCP) and bromophenol blue (method B) with absorption maxima at 404 and $410 \mathrm{~nm}$, respectively, for determination of sildenafil [94]. Salem et al. [95] reported the use of gold nanoparticles (Au NPs) for the assay of sildenafil citrate, tadalafil and vardenafil. Gold nanoparticles showed absorption at $522 \mathrm{~nm}$ but, after contact with the investigated drugs, the band at $522 \mathrm{~nm}$ disappeared with the formation of a new red-shifted band at 673,660 and $665 \mathrm{~nm}$ for sildenafil, tadalafil and vardenafil, respectively. This method showed good linearity in a concentration range of $0.1-12 \mu \mathrm{g} \mathrm{mL}^{-1}$ and was then used for the determination of these pharmaceuticals in pharmaceutical dosage forms and biological fluids (human serum and urine).

Despite providing several advantages such as being easy, cheap and not time-consuming, spectrophotometric techniques alone for quantifying drugs in biological and environmental matrices do not guarantee high selectivity and suffer from the interference of many compounds, which can compromise the results of the analysis. Accordingly, a previous separation step by liquid chromatography (LC) or capillary electrophoresis (CE) is typically used before detecting pharmaceuticals.

\subsection{Chromatographic Methods Coupled with UV/Vis Detectors and Mass Spectrometry (MS)}

Liquid chromatography coupled with UV/Vis and diode-array detectors (DAD) is commonly used to quantify pharmaceutical compounds in biological fluids and environmental and food samples. Generally, the separation is carried out on C18 columns with different mobile phase compositions for these techniques, although the most commonly used are acidified water, acetonitrile or methanol. Fidan and Bakirdere [96] developed a sensitive analytical method for the simultaneous determination of sildenafil and tadalafil and legal drugs and illegal/counterfeit drugs in wastewater samples by using a C18 column and phosphate buffer (35\%) and acetonitrile (65\%) as mobile phases and $225 \mathrm{~nm}$ as the wavelength of absorption. They calculated LOD/LOQ values of $28 / 92 \mathrm{ng} \mathrm{mL}^{-1}$ for sildenafil and 39/129 $\mathrm{ng} \mathrm{mL}^{-1}$ for tadalafil.

As said above, due to their popularity, medicinal products containing the PDE-5 inhibitors sildenafil, vardenafil and tadalafil are often subject to counterfeiting. In addition, illicit herbal dietary supplements adulterated with these substances or their analogues have appeared on the market, offering an easy and anonymous sale. Fejos et al. [97] reported an analytical method for the qualitative and quantitative screening of sildenafil, vardenafil, tadalafil and 11 of their designer analogues in illegal erectile dysfunction products by highperformance liquid chromatography with UV detection, using sildenafil as an external standard for the identification and quantification of all analytes. Also, in this case, a Kinetex C18 reverse-phased column was used. The elution was carried out with a gradient method using a mobile phase composed of a binary mixture of $200 \mathrm{mM}$ ammonium acetate solution (A) and $\mathrm{MeOH} / \mathrm{ACN}$ (B). The detection was performed ad $290 \mathrm{~nm}$. 
Although HPLC-UV methods are low cost and easy to use, LC-MS and LC-MS/MSbased methods are the most popular techniques for characterising pharmaceutical products and by-products in environmental samples. Naturally, the NMR is the elected technique to obtain the absolute configuration of a compound. But, the limit of NMR is the availability of a good amount of the substance to be analysed. For the determination of pollutants in micro- or nano-grams in environmental samples, some difficulties can arise. The ability of LC-MS-based methods to provide some structural information about the detected analytes makes them indispensable in the identification of low-concentration compounds and their unknown analogues and transformation products [98]. In detail, soft ionisation techniques such as electrospray ionisation (ESI) are generally used to ionise the drugs of interest effectively. The polarity is chosen for ionisation, i.e., the positive or the negative one depends on the relative acidity (pKa) of the functional groups occurring on the molecules [99]. As regard PDE- 5 inhibitors, positive polarity is typically used.

Öztürk Er et al. [100] validated a sensitive method for determining sildenafil and tadalafil using LC-QTOF-MS/MS and optimised both LC and MS parameters. They obtained very low LOD/LOQ values of $0.16 / 0.53$ and $0.28 / 0.93 \mathrm{ng} \mathrm{g}^{-1}$ for sildenafil and tadalafil, respectively. They successfully applied this method to analyse the two drugs by spiking experiments into all tested matrices into energy drinks, sewage sludge and tap water (Figure 8).
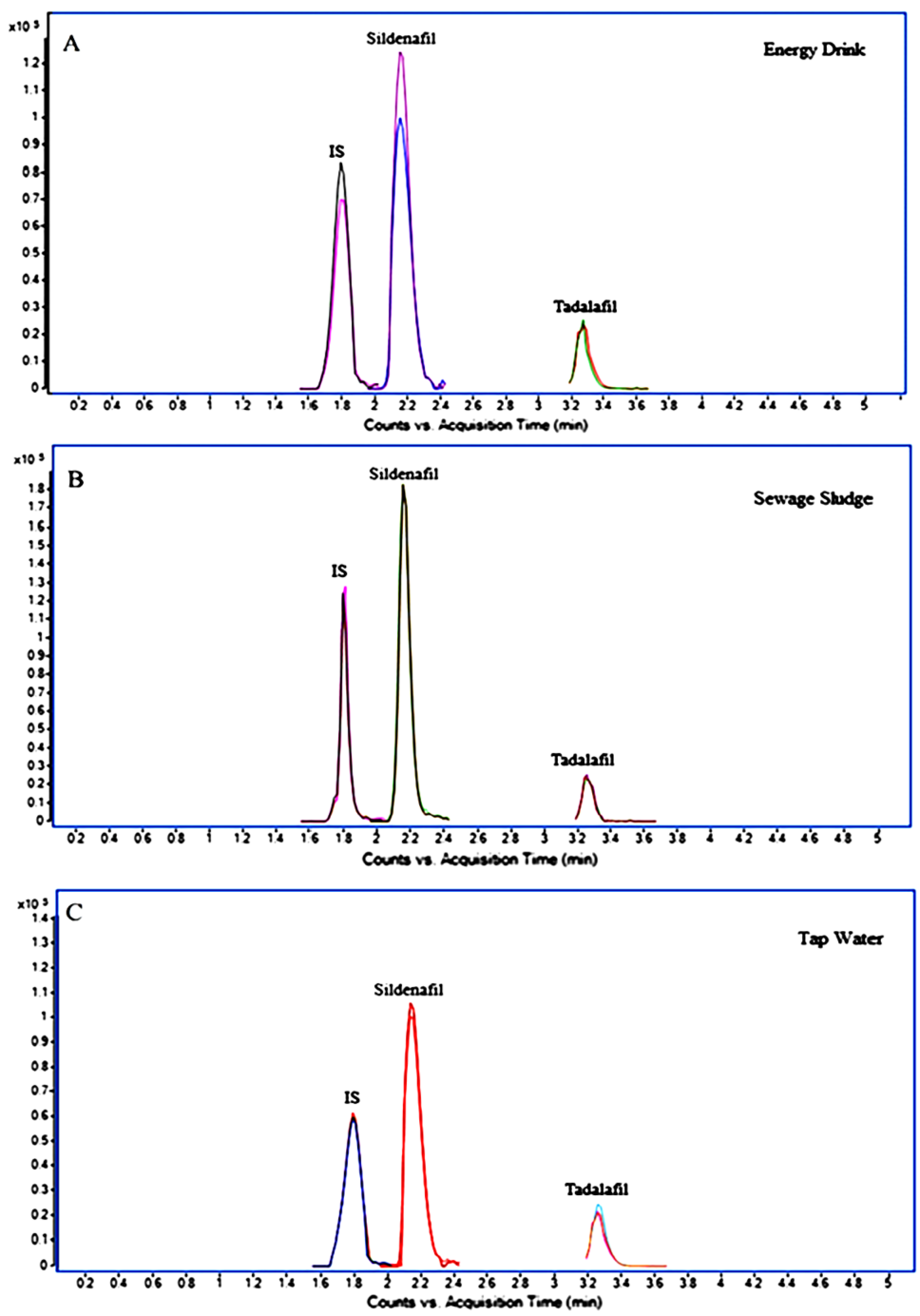

Figure 8. Spiking experiments for (A) energy drink, Brand E (B) sewage sludge and (C) tap water [100]. Reprinted with permission from ref. [100]. Copyright 2021 Elsevier. 
In addition, matrix effects were low and therefore acceptable: they ranged from $<9$ to $<19 \%$ for spiked urine, $<9 \%$ to $<18 \%$ for WWTP feed and $<5 \%$ to $<14 \%$ for WWTP effluent. As expected, matrix effects affecting ionisation increased from low-loaded effluent samples via feed samples to the heavily matrix-loaded fitness centre discharges. Therefore, LC-MS was a valid method applicable in quantification without stable isotope-labelled internal standards.

The developed method presents lower limits of detection/quantification and offers fast and direct analysis compared to other methodologies already published [101-103].

Öztürk Er et al. [104] also developed in 2019 another analytical method for the simultaneous determination of sildenafil, tadalafil, vardenafil and avanafil in human urine by the same instrumental system described above. The chromatographic separation of analytes was achieved by using a gradient elution method with a total run time of eight min and with ammonium formate/formic acid $(\mathrm{pH}=4.60)$ in ultrapure water $(\mathrm{A})$ and $0.10 \% v / v$ formic acid in acetonitrile (B) as mobile phase. This method provided a proper chromatographic separation of analytes with the retention times of 2.373, 2.845, 3.379 and $5.287 \mathrm{~min}$ for vardenafil, sildenafil, avanafil and tadalafil, respectively. MS/MS acquisitions were made using the electrospray interface in positive mode, and MS/MS transitions of each analyte were determined by adjusting the collision energy. The monitored transitions in the MS/MS experiments were $475.2155 \rightarrow 58.0652 / 100.0997 \mathrm{~m} / \mathrm{z}$ for sildenafil, 489.2247 $\rightarrow 151.0859 / 312.1574 \mathrm{~m} / \mathrm{z}$ for vardenafil, $484.1856 \rightarrow 375.1217 / 155.0254 \mathrm{~m} / \mathrm{z}$ for avanafil and $390.1441 \rightarrow 268.1076 / 135.0437$ for tadalafil, as quantifier/qualifier ion, respectively (Figure 9).
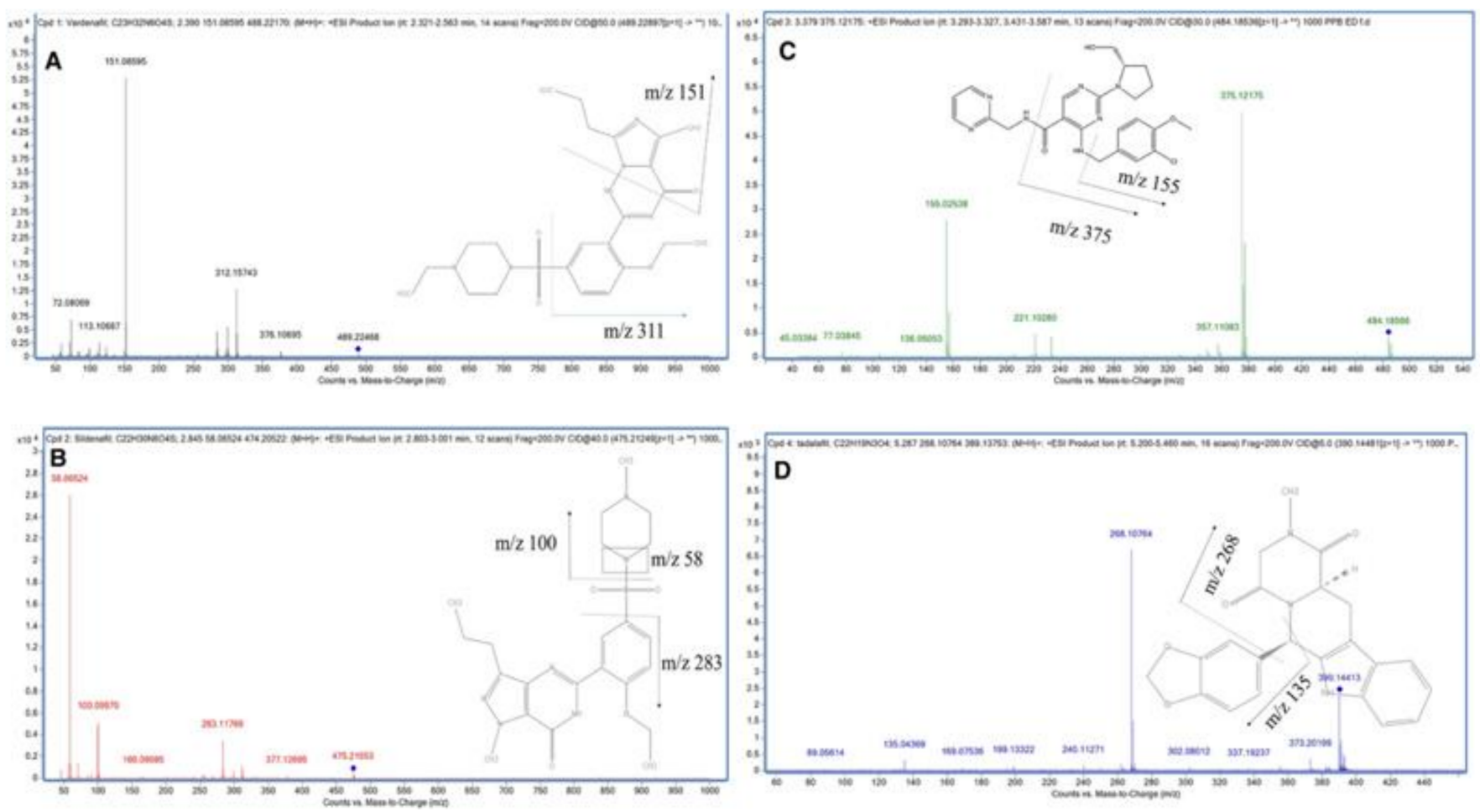

Figure 9. Full scan product ion mass spectra and proposed fragmentations of (A) vardenafil, (B) sildenafil, (C) avanafil and (D) tadalafil [104]. Reprinted with permission from ref. [104]. Copyright 2021 John Wiley and Sons.

The analytical performance of this method proved good linearity and low LOD/LOQ values, in particular, 2.28/7.59 $\mathrm{ng} \mathrm{g}^{-1}, 2.19 / 7.28 \mathrm{ng} \mathrm{g}^{-1}, 1.63 / 5.43 \mathrm{ng} \mathrm{g}^{-1}$ and 9.81/32.71 $\mathrm{ng} \mathrm{g}^{-1}$ for vardenafil, sildenafil, avanafil and tadalafil, respectively. Then, the method was successfully applied in human urine samples spiked with standard mixtures of each analyte. It was the first report for the simultaneous determination of FDA-approved active ingredients (sildenafil, tadalafil, vardenafil and avanafil) for ED drugs using MS/MS. 
The evaluation of matrix effects was also performed to investigate the potential interfering compounds in the urine matrix on the ionisation source. In detail, the analyte peak areas in the spiked urine sample were compared with the analyte peak areas in ultrapure water at the concentration of $60 \mathrm{ng} \mathrm{g}^{-1}$ for each compound. The matrix effect percentage was found to be below $10 \%$, which demonstrates a low matrix impact.

Some researchers have included sildenafil in multi-residue methods [105-107], and very few studies have analysed tadalafil and vardenafil [15] or have included metabolites and transformation products [45]. Indeed, as mentioned above, contaminants can undergo additional physical and chemical transformations in the environment due to abiotic (photolysis, hydrolysis) and biotic (biodegradation) reactions. Consequently, they can undergo structural modifications that lead to new transformation products, which may persist in the environment. LC-MS techniques play a central role in this contest because they allow elucidating structural information about TPs. Eichhorn et al. [48], Aceña et al. [108] and Herbert et al. [109] focused on some transformation products of sildenafil and vardenafil after the photodegradation process that appeared notably persistent, which might indicate a potential impact on the aquatic environment.

However, for these by-products, the literature mainly reported qualitative results. Therefore, a systematic method should be developed in the future to determine their concentration levels, LOD and LOQ values and matrix effect.

Eichorn et al. [48] performed the photolysis of sildenafil and its human metabolite $\mathrm{N}$-demethylsildenafil in ultrapure water, artificial freshwater, which resembled moderately hard water $\left(96 \mathrm{mg} \mathrm{L}{ }^{-1} \mathrm{NaHCO}_{3}, 60 \mathrm{mg} \mathrm{L}{ }^{-1} \mathrm{CaSO}_{4} \cdot 2 \mathrm{H}_{2} \mathrm{O}, 60 \mathrm{mg} \mathrm{L}^{-1} \mathrm{MgSO}_{4}\right.$ and $4 \mathrm{mg} \mathrm{L}^{-1} \mathrm{KCl} ; \mathrm{pH}$ 6.9), and natural river water ( $\mathrm{pH}$ 7.6). After chromatographic separation of the irradiated samples, eight photoproducts for sildenafil and six photoproducts for N-demethylsildenafil were detected and characterised using a combination of ultraperformance liquid chromatography-electrospray ionisation-quadrupole time-of-flightmass spectrometry (UPLC-ESI-QToF-MS), liquid chromatography-atmospheric pressure chemical ionisation-triple quadrupole mass spectrometry (LC-APCI-QqQ-MS) and hydrogen/deuterium exchange experiments, that allowed to propose plausible chemical structures for the photoproducts and to identify the piperazine ring as the main susceptible site of the photodegradation process (Tables 6 and 7).

Table 6. Accurate ion mass measurements of sildenafil and its phototransformation products obtained by UPLC-(+)ESIQToF-MS in MS and MS/MS mode [48]. Reprinted with permission from ref. [48]. Copyright 2021 John Wiley and Sons.

\begin{tabular}{|c|c|c|c|c|}
\hline $\begin{array}{l}\text { Compound/ } \\
\text { Photoproduct }\end{array}$ & $\begin{array}{c}\text { Measured Ion Mass of } \\
{[\mathbf{M}+\mathbf{H}]+}\end{array}$ & $\begin{array}{l}\text { Elemental } \\
\text { Composition }\end{array}$ & $\begin{array}{l}\text { Theoretical Ion Mass } \\
\qquad(\mathrm{m} / \mathrm{z})\end{array}$ & $\begin{array}{l}\text { Relative Error (ppm) } \\
\text { (DBE) }\end{array}$ \\
\hline \multirow{7}{*}{ SDF } & 475.2128 & $\mathrm{C}_{22} \mathrm{H}_{31} \mathrm{~N}_{6} \mathrm{O}_{4} \mathrm{~S}$ & 475.2132 & $+1.9(10.5)$ \\
\hline & 377.1285 & $\mathrm{C}_{17} \mathrm{H}_{21} \mathrm{~N}_{4} \mathrm{O}_{4} \mathrm{~S}$ & 377.1279 & $+1.6(9.5)$ \\
\hline & 311.1514 & $\mathrm{C}_{17} \mathrm{H}_{19} \mathrm{~N}_{4} \mathrm{O}_{2}$ & 311.1503 & $+3.5(10.5)$ \\
\hline & 299.1153 & $\mathrm{C}_{15} \mathrm{H}_{15} \mathrm{~N}_{4} \mathrm{O}_{3}$ & 299.1139 & $+4.7(10.5)$ \\
\hline & 283.1183 & $\mathrm{C}_{15} \mathrm{H}_{15} \mathrm{~N}_{4} \mathrm{O}_{2}$ & 283.119 & $-2.5(10.5)$ \\
\hline & 100.1033 & $\mathrm{C}_{5} \mathrm{H}_{12} \mathrm{~N}_{2}$ & 100.0995 & $+38(1.0)$ \\
\hline & 99.0938 & $\mathrm{C}_{5} \mathrm{H}_{11} \mathrm{~N}_{2}$ & 99.0917 & $+21.2(1.5)$ \\
\hline \multirow{9}{*}{ ТР490 } & 491.2089 & $\mathrm{C}_{22} \mathrm{H}_{31} \mathrm{~N}_{6} \mathrm{O}_{5} \mathrm{~S}$ & 491.2072 & $+3.5(10.5)$ \\
\hline & 473.1948 & $\mathrm{C}_{22} \mathrm{H}_{29} \mathrm{~N}_{6} \mathrm{O}_{4} \mathrm{~S}$ & 473.1966 & $-3.8(11.5)$ \\
\hline & 404.1382 & $\mathrm{C}_{18} \mathrm{H}_{22} \mathrm{~N}_{5} \mathrm{O}_{4} \mathrm{~S}$ & 404.1387 & $-1.2(10.5)$ \\
\hline & 377.1285 & $\mathrm{C}_{17} \mathrm{H}_{21} \mathrm{~N}_{4} \mathrm{O}_{4} \mathrm{~S}$ & 377.1279 & $+1.6(9.5)$ \\
\hline & 311.1518 & $\mathrm{C}_{17} \mathrm{H}_{19} \mathrm{~N}_{4} \mathrm{O}_{2}$ & 311.1503 & $+4.8(10.5)$ \\
\hline & 299.1152 & $\mathrm{C}_{15} \mathrm{H}_{15} \mathrm{~N}_{4} \mathrm{O}_{3}$ & 299.1139 & $+4.3(10.5)$ \\
\hline & 283.12 .5 & $\mathrm{C}_{15} \mathrm{H}_{15} \mathrm{~N}_{4} \mathrm{O}_{2}$ & 283.1190 & $+4.6(10.5)$ \\
\hline & 100.1012 & $\mathrm{C}_{5} \mathrm{H}_{12} \mathrm{~N}_{2}$ & 100.0995 & $+17(1.0)$ \\
\hline & 99.0940 & $\mathrm{C}_{5} \mathrm{H}_{11} \mathrm{~N}_{2}$ & 99.0917 & $+28.3(1.5)$ \\
\hline
\end{tabular}


Table 6. Cont.

\begin{tabular}{|c|c|c|c|c|}
\hline $\begin{array}{l}\text { Compound/ } \\
\text { Photoproduct }\end{array}$ & $\begin{array}{l}\text { Measured Ion Mass of } \\
\qquad[\mathbf{M}+\mathbf{H}]+\end{array}$ & $\begin{array}{c}\text { Elemental } \\
\text { Composition }\end{array}$ & $\begin{array}{l}\text { Theoretical Ion Mass } \\
\qquad(\mathrm{m} / \mathrm{z})\end{array}$ & $\begin{array}{c}\text { Relative Error (ppm) } \\
\text { (DBE) }\end{array}$ \\
\hline \multirow{7}{*}{ ТР488-C } & 489.1952 & $\mathrm{C}_{22} \mathrm{H}_{29} \mathrm{~N}_{6} \mathrm{O}_{5} \mathrm{~S}$ & 489.191 & $+4.5(11.5)$ \\
\hline & 461.1997 & $\mathrm{C}_{21} \mathrm{H}_{29} \mathrm{~N}_{6} \mathrm{O}_{4} \mathrm{~S}$ & 461.1966 & $+6.7(10.5)$ \\
\hline & 377.1296 & $\mathrm{C}_{17} \mathrm{H}_{21} \mathrm{~N}_{4} \mathrm{O}_{4} \mathrm{~S}$ & 377.1279 & $+4.5(9.5)$ \\
\hline & 311.1511 & $\mathrm{C}_{17} \mathrm{H}_{19} \mathrm{~N}_{4} \mathrm{O}_{2}$ & 311.1503 & $+2.6(10.5)$ \\
\hline & 299.1146 & $\mathrm{C}_{15} \mathrm{H}_{15} \mathrm{~N}_{4} \mathrm{O}_{3}$ & 299.1139 & $+2.3(10.5)$ \\
\hline & 283.1183 & $\mathrm{C}_{15} \mathrm{H}_{15} \mathrm{~N}_{4} \mathrm{O}_{2}$ & 283.1190 & $-2.5(10.5)$ \\
\hline & 85.0727 & $\mathrm{C}_{4} \mathrm{H}_{9} \mathrm{~N}_{2}$ & 85.0760 & $-38.8(1.5)$ \\
\hline \multirow{6}{*}{ ТР462 } & 463.1777 & $\mathrm{C}_{20} \mathrm{H}_{27} \mathrm{~N}_{6} \mathrm{O}_{5} \mathrm{~S}$ & 463.1758 & $+4.1(10.5)$ \\
\hline & 435.1836 & $\mathrm{C}_{19} \mathrm{H}_{27} \mathrm{~N}_{6} \mathrm{O}_{4} \mathrm{~S}$ & 435.1809 & $+4.1(9.5)$ \\
\hline & 418.1517 & $\mathrm{C}_{19} \mathrm{H}_{24} \mathrm{~N}_{5} \mathrm{O}_{4} \mathrm{~S}$ & 418.1544 & $-6.5(10.5)$ \\
\hline & 311.153 & $\mathrm{C}_{17} \mathrm{H}_{19} \mathrm{~N}_{4} \mathrm{O}_{2}$ & 311.1503 & $+8.7(10.5)$ \\
\hline & 299.1155 & $\mathrm{C}_{15} \mathrm{H}_{15} \mathrm{~N}_{4} \mathrm{O}_{3}$ & 299.1139 & $+5.3(10.5)$ \\
\hline & 283.1178 & $\mathrm{C}_{15} \mathrm{H}_{15} \mathrm{~N}_{4} \mathrm{O}_{2}$ & 283.1190 & $-4.2(10.5)$ \\
\hline \multirow{5}{*}{ ТР460 } & 461.1986 & $\mathrm{C}_{21} \mathrm{H}_{29} \mathrm{~N}_{6} \mathrm{O}_{4} \mathrm{~S}$ & 461.1966 & $+4.3(10.5)$ \\
\hline & 377.1285 & $\mathrm{C}_{17} \mathrm{H}_{21} \mathrm{~N}_{4} \mathrm{O}_{4} \mathrm{~S}$ & 377.1279 & $+1.6(9.5)$ \\
\hline & 311.1511 & $\mathrm{C}_{17} \mathrm{H}_{19} \mathrm{~N}_{4} \mathrm{O}_{2}$ & 311.1503 & $+2.6(10.5)$ \\
\hline & 283.1185 & $\mathrm{C}_{15} \mathrm{H}_{18} \mathrm{~N}_{4} \mathrm{O}_{2}$ & 283.119 & $-1.8(10.5)$ \\
\hline & 85.0769 & $\mathrm{C}_{4} \mathrm{H}_{9} \mathrm{~N}_{2}$ & 85.0760 & $+9.4(1.5)$ \\
\hline \multirow{7}{*}{ ТP448-A } & 449.2163 & $\mathrm{C}_{20} \mathrm{H}_{29} \mathrm{~N}_{6} \mathrm{O}_{4} \mathrm{~S}$ & 449.1966 & $+5.1(9.5)$ \\
\hline & 418.1529 & $\mathrm{C}_{19} \mathrm{H}_{24} \mathrm{~N}_{5} \mathrm{O}_{4} \mathrm{~S}$ & 418.1544 & $-3.6(10.5)$ \\
\hline & 392.1363 & $\mathrm{C}_{19} \mathrm{H}_{24} \mathrm{~N}_{5} \mathrm{O}_{4} \mathrm{~S}$ & 392.1387 & $-6.1(9.5)$ \\
\hline & 377.129 & $\mathrm{C}_{17} \mathrm{H}_{21} \mathrm{~N}_{4} \mathrm{O}_{4} \mathrm{~S}$ & 377.1279 & $+2.9(9.5)$ \\
\hline & 311.1489 & $\mathrm{C}_{17} \mathrm{H}_{19} \mathrm{~N}_{4} \mathrm{O}_{2}$ & 311.1503 & $-4.5(10.5)$ \\
\hline & 299.1151 & $\mathrm{C}_{15} \mathrm{H}_{15} \mathrm{~N}_{4} \mathrm{O}_{3}$ & 299.1139 & $+4.0(10.5)$ \\
\hline & 283.1203 & $\mathrm{C}_{15} \mathrm{H}_{15} \mathrm{~N}_{4} \mathrm{O}_{2}$ & 283.1190 & $+4.6(10.5)$ \\
\hline \multirow{7}{*}{ ТP434 } & 435.1834 & $\mathrm{C}_{19} \mathrm{H}_{27} \mathrm{~N}_{6} \mathrm{O}_{4} \mathrm{~S}$ & 435.1814 & $+5.7(9.5)$ \\
\hline & 418.1567 & $\mathrm{C}_{19} \mathrm{H}_{24} \mathrm{~N}_{5} \mathrm{O}_{4} \mathrm{~S}$ & 418.1544 & $+5.5(10.5)$ \\
\hline & 392.1451 & $\mathrm{C}_{17} \mathrm{H}_{22} \mathrm{~N}_{5} \mathrm{O}_{4} \mathrm{~S}$ & 392.1387 & $+5.6(9.5)$ \\
\hline & 377.1245 & $\mathrm{C}_{17} \mathrm{H}_{21} \mathrm{~N}_{4} \mathrm{O}_{4} \mathrm{~S}$ & 377.1279 & $-9.0(9.5)$ \\
\hline & 311.1516 & $\mathrm{C}_{17} \mathrm{H}_{19} \mathrm{~N}_{4} \mathrm{O}_{2}$ & 311.1503 & $+4.2(10.5)$ \\
\hline & 299.1159 & $\mathrm{C}_{15} \mathrm{H}_{15} \mathrm{~N}_{4} \mathrm{O}_{3}$ & 299.1139 & $+6.7(10.5)$ \\
\hline & 283.1205 & $\mathrm{C}_{15} \mathrm{H}_{15} \mathrm{~N}_{4} \mathrm{O}_{2}$ & 283.1190 & $+5.3(10.5)$ \\
\hline \multirow{5}{*}{ ТP392 } & 393.1234 & $\mathrm{C}_{17} \mathrm{H}_{21} \mathrm{~N}_{4} \mathrm{O}_{5} \mathrm{~S}$ & 393.1227 & $+1.5(9.5)$ \\
\hline & 365.0903 & $\mathrm{C}_{15} \mathrm{H}_{17} \mathrm{~N}_{4} \mathrm{O}_{5} \mathrm{~S}$ & 365.0914 & $-3.0(9.5)$ \\
\hline & 336.0637 & $\mathrm{C}_{14} \mathrm{H}_{14} \mathrm{~N}_{3} \mathrm{O}_{5} \mathrm{~S}$ & 336.0649 & $-3.6(9.5)$ \\
\hline & 284.1279 & $\mathrm{C}_{15} \mathrm{H}_{16} \mathrm{~N}_{4} \mathrm{O}_{2}$ & 284.1268 & $3.9(10.0)$ \\
\hline & 256.1070 & $\mathrm{C}_{14} \mathrm{H}_{14} \mathrm{~N}_{3} \mathrm{O}_{2}$ & 256.1081 & $-4.3(9.5)$ \\
\hline \multirow{4}{*}{ TP391 } & 392.1365 & $\mathrm{C}_{17} \mathrm{H}_{22} \mathrm{~N}_{5} \mathrm{O}_{4} \mathrm{~S}$ & 392.1387 & $-5.6(9.5)$ \\
\hline & 364.1056 & $\mathrm{C}_{15} \mathrm{H}_{18} \mathrm{~N}_{5} \mathrm{O}_{4} \mathrm{~S}$ & 364.1079 & $-6.3(9.5)$ \\
\hline & 299.1157 & $\mathrm{C}_{15} \mathrm{H}_{15} \mathrm{~N}_{4} \mathrm{O}_{3}$ & 299.1139 & $+6.0(10.5)$ \\
\hline & 283.1169 & $\mathrm{C}_{15} \mathrm{H}_{15} \mathrm{~N}_{4} \mathrm{O}_{2}$ & 283.1190 & $-7.4(10.5)$ \\
\hline
\end{tabular}


Table 7. Accurate ion mass measurements of N-demethylsildenafil and its phototransformation products obtained by UPLC-(+)ESI-QToF-MS in MS and MS/MS mode [48]. Reprinted with permission from ref. [48]. Copyright 2021 John Wiley and Sons.

\begin{tabular}{|c|c|c|c|c|}
\hline $\begin{array}{l}\text { Compound/ } \\
\text { Photoproduct }\end{array}$ & $\begin{array}{c}\text { Measured Ion Mass of } \\
{[\mathbf{M}+\mathbf{H}]+}\end{array}$ & $\begin{array}{c}\text { Elemental } \\
\text { Composition }\end{array}$ & $\begin{array}{l}\text { Theoretical Ion Mass } \\
\qquad(\mathrm{m} / \mathrm{z})\end{array}$ & Relative Error (ppm) \\
\hline \multirow{6}{*}{ DM-SDF } & 461.1978 & $\begin{array}{l}\mathrm{C}_{21} \mathrm{H}_{29} \mathrm{~N}_{6} \mathrm{O}_{4} \mathrm{~S} \\
\mathrm{C}_{17} \mathrm{H}_{21} \mathrm{~N}_{4} \mathrm{O}_{4} \mathrm{~S} \\
\mathrm{C}_{17} \mathrm{H}_{19} \mathrm{~N}_{4} \mathrm{O}_{2}\end{array}$ & 461.1966 & $+2.6(10.5)$ \\
\hline & 377.1270 & $\mathrm{C}_{15} \mathrm{H}_{15} \mathrm{~N}_{4} \mathrm{O}_{3}$ & 377.1279 & $-2.4(9.5)$ \\
\hline & 311.1518 & $\mathrm{C}_{15} \mathrm{H}_{15} \mathrm{~N}_{4} \mathrm{O}_{2}$ & 311.1503 & $+4.8(10.5)$ \\
\hline & 299.1155 & $\mathrm{C}_{4} \mathrm{H}_{9} \mathrm{~N}_{2}$ & 299.1139 & $+5.3(10.5)$ \\
\hline & 283.1203 & & 283.1190 & $+4.6(10.5)$ \\
\hline & 85.0803 & & 85.0760 & $-11.8(1.5)$ \\
\hline \multirow{7}{*}{ TP476 } & 477.1959 & $\mathrm{C}_{21} \mathrm{H}_{29} \mathrm{~N}_{6} \mathrm{O}_{5} \mathrm{~S}$ & 477.1915 & $+9.2(10.5)$ \\
\hline & 404.1404 & $\mathrm{C}_{18} \mathrm{H}_{22} \mathrm{~N}_{5} \mathrm{O}_{4} \mathrm{~S}$ & 404.1387 & $+7.9(10.5)$ \\
\hline & 377.1295 & $\mathrm{C}_{17} \mathrm{H}_{21} \mathrm{~N}_{4} \mathrm{O}_{4} \mathrm{~S}$ & 377.1278 & $+4.5(9.5)$ \\
\hline & 331.0836 & $\mathrm{C}_{15} \mathrm{H}_{15} \mathrm{~N}_{4} \mathrm{O}_{3} \mathrm{~S}$ & 331.0865 & $-5.7(10.5)$ \\
\hline & 312.1597 & $\mathrm{C}_{17} \mathrm{H}_{20} \mathrm{~N}_{4} \mathrm{O}_{2}$ & 312.1581 & $+5.1(10.0)$ \\
\hline & 283.1205 & $\mathrm{C}_{15} \mathrm{H}_{15} \mathrm{~N}_{4} \mathrm{O}_{2}$ & 283.1190 & $+4.6(10.5)$ \\
\hline & 83.0628 & $\mathrm{C}_{4} \mathrm{H}_{7} \mathrm{~N}_{2}$ & 83.0604 & $+28.9(2.5)$ \\
\hline \multirow{6}{*}{ ТР462 } & 463.1777 & $\mathrm{C}_{20} \mathrm{H}_{27} \mathrm{~N}_{6} \mathrm{O}_{5} \mathrm{~S}$ & 463.1758 & $+4.1(10.5)$ \\
\hline & 435.1839 & $\mathrm{C}_{19} \mathrm{H}_{27} \mathrm{~N}_{6} \mathrm{O}_{4} \mathrm{~S}$ & 435.1809 & $+6.9(9.5)$ \\
\hline & 418.1569 & $\mathrm{C}_{19} \mathrm{H}_{24} \mathrm{~N}_{5} \mathrm{O}_{4} \mathrm{~S}$ & 418.1544 & $+6.0(10.5)$ \\
\hline & 311.1520 & $\mathrm{C}_{17} \mathrm{H}_{19} \mathrm{~N}_{4} \mathrm{O}_{2}$ & 311.1503 & $+5.5(10.5)$ \\
\hline & 299.1122 & $\mathrm{C}_{15} \mathrm{H}_{15} \mathrm{~N}_{4} \mathrm{O}_{3}$ & 299.1139 & $-5.7(10.5)$ \\
\hline & 283.1175 & $\mathrm{C}_{15} \mathrm{H}_{15} \mathrm{~N}_{4} \mathrm{O}_{2}$ & 283.1190 & $-5.3(10.5)$ \\
\hline \multirow{6}{*}{ ТР448-B } & 449.162 & $\mathrm{C}_{19} \mathrm{H}_{25} \mathrm{~N}_{6} \mathrm{O}_{5} \mathrm{~S}$ & 449.1602 & $+4.0(10.5)$ \\
\hline & 431.1507 & $\mathrm{C}_{19} \mathrm{H}_{23} \mathrm{~N}_{6} \mathrm{O}_{4} \mathrm{~S}$ & 431.1496 & $+2.6(11.5)$ \\
\hline & 404.1393 & $\mathrm{C}_{18} \mathrm{H}_{22} \mathrm{~N}_{5} \mathrm{O}_{4} \mathrm{~S}$ & 404.1387 & $+0.2(10.5)$ \\
\hline & 311.1519 & $\mathrm{C}_{17} \mathrm{H}_{19} \mathrm{~N}_{4} \mathrm{O}_{2}$ & 311.1503 & $+5.1(10.5)$ \\
\hline & 299.1122 & $\mathrm{C}_{15} \mathrm{H}_{15} \mathrm{~N}_{4} \mathrm{O}_{3}$ & 299.1139 & $-5.7(10.5)$ \\
\hline & 283.1206 & $\mathrm{C}_{15} \mathrm{H}_{15} \mathrm{~N}_{4} \mathrm{O}_{2}$ & 283.1190 & $+5.7(10.5)$ \\
\hline \multirow{7}{*}{ ТP434 } & 435.1801 & $\mathrm{C}_{19} \mathrm{H}_{25} \mathrm{~N}_{6} \mathrm{O}_{5} \mathrm{~S}$ & 435.181 & $-2.1(9.5)$ \\
\hline & 418.1539 & $\mathrm{C}_{19} \mathrm{H}_{22} \mathrm{~N}_{5} \mathrm{O}_{4} \mathrm{~S}$ & 418.1544 & $-1.2(10.5)$ \\
\hline & 392.1353 & $\mathrm{C}_{17} \mathrm{H}_{22} \mathrm{~N}_{5} \mathrm{O}_{4} \mathrm{~S}$ & 392.1387 & $-8.7(9.5)$ \\
\hline & 377.1281 & $\mathrm{C}_{17} \mathrm{H}_{21} \mathrm{~N}_{4} \mathrm{O}_{4} \mathrm{~S}$ & 377.1279 & $+0.5(9.5)$ \\
\hline & 311.1514 & $\mathrm{C}_{17} \mathrm{H}_{19} \mathrm{~N}_{4} \mathrm{O}_{2}$ & 311.1503 & $+3.5(10.5)$ \\
\hline & 299.1126 & $\mathrm{C}_{15} \mathrm{H}_{15} \mathrm{~N}_{4} \mathrm{O}_{3}$ & 299.1139 & $-4.3(10.5)$ \\
\hline & 283.1197 & $\mathrm{C}_{15} \mathrm{H}_{15} \mathrm{~N}_{4} \mathrm{O}_{2}$ & 283.1190 & $+2.5(10.5)$ \\
\hline \multirow{6}{*}{ TP392 } & 393.1248 & $\mathrm{C}_{17} \mathrm{H}_{21} \mathrm{~N}_{4} \mathrm{O}_{5} \mathrm{~S}$ & 393.1227 & $+5.3(9.5)$ \\
\hline & 365.0922 & $\mathrm{C}_{15} \mathrm{H}_{17} \mathrm{~N}_{4} \mathrm{O}_{5} \mathrm{~S}$ & 365.0914 & $+2.2(9.5)$ \\
\hline & 365.0922 & $\mathrm{C}_{15} \mathrm{H}_{17} \mathrm{~N}_{4} \mathrm{O}_{5} \mathrm{~S}$ & 365.0914 & $+2.2(9.5)$ \\
\hline & 336.0627 & $\mathrm{C}_{14} \mathrm{H}_{14} \mathrm{~N}_{3} \mathrm{O}_{5} \mathrm{~S}$ & 336.0649 & $-6.5(9.5)$ \\
\hline & 284.1290 & $\mathrm{C}_{15} \mathrm{H}_{16} \mathrm{~N}_{4} \mathrm{O}_{2}$ & 284.1268 & $+7.7(10.0)$ \\
\hline & 256.1060 & $\mathrm{C}_{14} \mathrm{H}_{14} \mathrm{~N}_{3} \mathrm{O}_{2}$ & 256.1081 & $-8.2(9.5)$ \\
\hline \multirow{4}{*}{ ТP391 } & 392.1405 & $\mathrm{C}_{17} \mathrm{H}_{22} \mathrm{~N}_{5} \mathrm{O}_{4} \mathrm{~S}$ & 392.1387 & $+3.1(9.5)$ \\
\hline & 364.1105 & $\mathrm{C}_{15} \mathrm{H}_{18} \mathrm{~N}_{5} \mathrm{O}_{4} \mathrm{~S}$ & 364.1079 & $-0.5(9.5)$ \\
\hline & 299.1158 & $\mathrm{C}_{15} \mathrm{H}_{15} \mathrm{~N}_{4} \mathrm{O}_{3}$ & 299.1139 & $+6.4(10.5)$ \\
\hline & 283.1172 & $\mathrm{C}_{15} \mathrm{H}_{15} \mathrm{~N}_{4} \mathrm{O}_{2}$ & 283.1190 & $-6.4(10.5)$ \\
\hline
\end{tabular}

Following ESI(+), the acquisition of the product ion spectrum of the protonated sildenafil and $\mathrm{N}$-demethylsildenafil gave rise to a number of characteristic fragment ions. Most of them are the same for both compounds.

The results of sildenafil and $\mathrm{N}$-sildenafil photolysis evidenced that the piperazine ring in these molecules can be broken down with relative ease under the influence of artificial sunlight until reaching the stage of the sulfonic acid as a key intermediate. 
It is interesting to note that the fate of sildenafil under irradiation followed a similar path that occurs in the human body. The cocktail of possible metabolites (human and not) released into the environment through wastewater discharges and the possibility of $\mathrm{N}$-sildenafil undergoing photoreactions evidence the contamination issue.

Herbert et al. [109] successively compared and identified the photoproducts obtained after 48-96 h of irradiation for vardenafil and sildenafil (Table 8) by LC-ESI-MS and MS/MS. Most of these photoproducts resulted from cleavages within the alkylated piperazine ring. Several photoproducts confirmed the previous report by Eichhorn et al. [48]. The compound represented the only exception at $m / z 476$, a transformation product with an opening in the fused heterocyclic moieties instead of the piperazinic ring.

Sildenafil 476 and vardenafil 490 were the unique transformation substances detected with an opening of the fused heterocyclic (pyrazolopyrimidione) moiety within the two compounds; in these products, the alkylated piperazine ring remains intact. The MS/MS spectrum for sildenafil 476 included a major fragment at $m / z$ 449. The spectrum for vardenafil 490 displayed a constituent at $m / z 463$, both of which point to an opening in the heterocyclic ring. These products represent a small but significant portion of the overall photoproducts observed in this study even after $96 \mathrm{~h}$ of photo exposure.

Table 9 reports a summary of the main LC-MS methods used to determine PDE-5 inhibitors in the last years.

Table 8. LC-MS data and proposed structures of vardenafil (VRD) and sildenafil (SLD) PT products [109]. Reprinted with permission from ref. [109]. Copyright 2021 Elsevier.

\begin{tabular}{|c|c|c|c|c|c|c|c|}
\hline \multicolumn{4}{|c|}{ VRD Phototransformation (PT) Products } & \multicolumn{4}{|c|}{ SLD Phototransformation (PT) Products } \\
\hline $\operatorname{Rt}(\mathbf{m})$ & $\mathrm{m} / \mathrm{z}(\mathrm{Da})$ & Proposed Structure & Name & $\operatorname{Rt}(\mathrm{m})$ & $m / z$ (Da) & Proposed Structure & Name \\
\hline 2.8 & 393 & & VRD-392 & 3.8 & 393 & & SLD-392 \\
\hline 5.3 & 392 & & VRD-391 & 9.6 & 392 & & SLD-391 \\
\hline 5.6 & 463 & & VRD-462 & 6.9 & 449 & & SLD-448 \\
\hline & 435 & ND & & 6.6 & 435 & & SLD-434 \\
\hline 6.7 & 461 & & VRD-460 & & 461 & & SLD-460 \\
\hline 6.8 & 489 & & VRD & & 475 & & SLD \\
\hline
\end{tabular}


Table 8. Cont.

\begin{tabular}{|c|c|c|c|c|c|c|c|}
\hline \multicolumn{4}{|c|}{ VRD Phototransformation (PT) Products } & \multicolumn{4}{|c|}{ SLD Phototransformation (PT) Products } \\
\hline $\operatorname{Rt}(\mathbf{m})$ & $\mathrm{m} / \mathrm{z}(\mathrm{Da})$ & Proposed Structure & Name & $\operatorname{Rt}(\mathbf{m})$ & $m / z$ (Da) & Proposed Structure & Name \\
\hline & $(463)$ & ND & & & 463 & & SLD-462 \\
\hline 7.1 & 505 & & VRD-504 & & 491 & & SLD-490 \\
\hline 8.4 & 491 & & VRD-490 & & 477 & & SLD-476 \\
\hline
\end{tabular}

Table 9. Main LC-MS methods reported in the literature for detecting sildenafil, tadalafil, vardenafil and avanafil.

\begin{tabular}{|c|c|c|c|c|c|}
\hline $\begin{array}{l}\text { Investigated } \\
\text { Compound }\end{array}$ & Sample Matrix & Sample Preparation & Detection Method & LOD/LOQ & Reference \\
\hline $\begin{array}{l}\text { Sildenafil, } \\
\text { Tadalafil, } \\
\text { Vardenafil }\end{array}$ & $\begin{array}{l}\text { Influent wastewater, } \\
\text { effluent wastewater } \\
\text { and sewage } \\
\text { sludge samples }\end{array}$ & $\begin{array}{c}\text { Wastewater samples } \\
\text { Solid-phase extraction } \\
\text { (SPE) } \\
\text { Sewage sludge samples } \\
\text { Pressurised liquid } \\
\text { extraction (PLE) }\end{array}$ & HPLC-MS/MS & $\begin{array}{l}\text { Sildenafil } \\
\text { Influent wastewater } \\
\text { LOD: } 1 \mathrm{ng} \mathrm{L}^{-1} \\
\text { LOQ: } 2.5 \mathrm{ng} \mathrm{L}^{-1} \\
\text { Effluent wastewater } \\
\text { LOD: } 1 \mathrm{ng} \mathrm{L}^{-1} \\
\text { LOQ: } 1 \mathrm{ng} \mathrm{L}^{-1} \\
\text { Sewage sludge } \\
\text { LOD: } 1 \mathrm{ng} \mathrm{g}^{-1} \\
\text { LOQ: } 3 \mathrm{ng} \mathrm{g}^{-1} \\
\text { Tadalafil } \\
\text { Influent wastewater } \\
\text { LOD: } 5 \mathrm{ng} \mathrm{L}^{-1} \\
\text { LOQ: } 6 \mathrm{ng} \mathrm{L}^{-1} \\
\text { Effluent wastewater } \\
\text { LOD: } 1.5 \mathrm{ng} \mathrm{L}^{-1} \\
\text { LOQ: } 2.5 \mathrm{ng} \mathrm{L}^{-1} \\
\text { Sewage sludge } \\
\text { LOD: } 3 \mathrm{ng} \mathrm{g}^{-1} \\
\text { LOQ: } 5 \mathrm{ng} \mathrm{g}^{-1} \\
\text { Vardenafil } \\
\text { Influent wastewater } \\
\text { LOD: } 2 \mathrm{ng} \mathrm{L}^{-1} \\
\text { LOQ: } 4 \mathrm{ng} \mathrm{L}^{-1} \\
\text { Effluent wastewater } \\
\text { LOD: } 1 \mathrm{ng} \mathrm{L}^{-1} \\
\text { LOQ: } 1.5 \mathrm{ng} \mathrm{L}^{-1} \\
\text { Sewage sludge } \\
\text { LOD: } 2 \mathrm{ng} \mathrm{g}^{-1} \\
\text { LOQ: } 5 \mathrm{ng} \mathrm{g}^{-1}\end{array}$ & [15] \\
\hline
\end{tabular}


Table 9. Cont.

\begin{tabular}{|c|c|c|c|c|c|}
\hline $\begin{array}{l}\text { Investigated } \\
\text { Compound }\end{array}$ & Sample Matrix & Sample Preparation & Detection Method & LOD/LOQ & Reference \\
\hline $\begin{array}{l}\text { Sildenafil, } \\
\text { Tadalafil, } \\
\text { Vardenafil }\end{array}$ & Wastewater samples & $\begin{array}{l}\text { Homogenisation, } \\
\text { spiking with deuterated } \\
\text { analogue and filtration } \\
\text { with } 0.2 \mu \mathrm{m} \\
\text { syringe filter }\end{array}$ & UPLC-MS/MS & $\begin{array}{l}\text { Sildenafil } \\
\text { LOD: } 2 \text { ng L } \\
\text { LOQ: } 6 \text { ng L } \\
\text { Tadalafil } \\
\text { LOD: } 2 \text { ng L L } \\
\text { LOQ: } 8 \text { ng L } \\
\text { Vardenafil } \\
\text { LOD: } 7 \text { ng L } \\
\text { LOQ: } 24 \mathrm{ng} \mathrm{L}^{-1}\end{array}$ & [44] \\
\hline $\begin{array}{l}\text { Sildenafil, } \\
\text { Tadalafil, } \\
\text { Vardenafil } \\
\text { and their } \\
\text { metabolites }\end{array}$ & $\begin{array}{c}\text { Spiked urine and } \\
\text { wastewater samples }\end{array}$ & $\begin{array}{c}\text { Solid-phase } \\
\text { extraction (SPE) }\end{array}$ & $\begin{array}{l}\text { HPLC-(HR)- } \\
\text { MS/MS }\end{array}$ & $\begin{array}{c}\text { Sildenafil } \\
\text { Spiked urine } \\
\text { LLOD: }<2 \mathrm{ng} \mathrm{L}^{-1} \\
\text { LLOQ: } 2 \mathrm{ng} \mathrm{L}^{-1} \\
\text { Spiked wastewater } \\
\text { LLOD: }<1 \mathrm{ng} \mathrm{L}^{-1} \\
\text { LLOQ: } 2 \mathrm{ng} \mathrm{L}^{-1} \\
\text { Tadalafil } \\
\text { Spiked urine } \\
\text { LLOD: }<2 \mathrm{ng} \mathrm{L}^{-1} \\
\text { LLOQ: } 2 \mathrm{ng} \mathrm{L}^{-1} \\
\text { Spiked wastewater } \\
\text { LLOD: }<1 \mathrm{ng} \mathrm{L}^{-1} \\
\text { LLOQ: } 2 \mathrm{ng} \mathrm{L}^{-1} \\
\text { Vardenafil } \\
\text { Spiked urine } \\
\text { LLOD: }<2 \mathrm{ng} \mathrm{L}^{-1} \\
\text { LLOQ: } 2 \mathrm{ng} \mathrm{L}^{-1} \\
\text { Spiked wastewater } \\
\text { LLOD: }<1 \mathrm{ng} \mathrm{L}^{-1} \\
\text { LLOQ: } 2 \mathrm{ng} \mathrm{L}^{-1}\end{array}$ & [45] \\
\hline $\begin{array}{l}\text { Sildenafil, } \\
\text { N-desmethyl } \\
\text { sildenafil and } \\
\text { their photo- } \\
\text { transformation } \\
\text { products }\end{array}$ & $\begin{array}{l}\text { Ultrapure water, } \\
\text { artificial freshwater, } \\
\text { natural river water }\end{array}$ & $\begin{array}{l}\text { Irradiation of tests } \\
\text { solution in the } \\
3 \text { matrices, with an } \\
\text { initial concentration of } \\
10 \mathrm{mg} \mathrm{L}^{-1}\end{array}$ & $\begin{array}{l}\text { UPLC-ESI- } \\
\text { QToF-MS }\end{array}$ & Not reported & [48] \\
\hline $\begin{array}{l}\text { Sildenafil and } \\
\text { Tadalafil }\end{array}$ & $\begin{array}{l}\text { Standard solutions, } \\
\text { tap water, energy } \\
\text { drinks, sewage } \\
\text { sludge }\end{array}$ & $\begin{array}{c}\text { Energy drink } \\
\text { Direct injection } \\
\text { Tap water and sewage } \\
\text { sludge } \\
\text { Dilution with } 50 / 50 \\
(v / v) \text { ACN } / \text { water and } \\
\text { filtration with a } 0.45 \mu \mathrm{m} \\
\text { syringe filter }\end{array}$ & LC-QTOF-MS/MS & $\begin{array}{l}\text { Sildenafil } \\
\text { LOD: } 0.16 \mathrm{ng} \mathrm{g}^{-1} \\
\text { LOQ: } 0.53 \mathrm{ng} \mathrm{g}^{-1} \\
\text { Tadalafil } \\
\text { LOD: } 0.28 \mathrm{ng} \mathrm{g}^{-1} \\
\text { LOQ: } 0.93 \mathrm{ng} \mathrm{g}^{-1}\end{array}$ & [100] \\
\hline
\end{tabular}


Table 9. Cont.

\begin{tabular}{|c|c|c|c|c|c|}
\hline $\begin{array}{l}\text { Investigated } \\
\text { Compound }\end{array}$ & Sample Matrix & Sample Preparation & Detection Method & LOD/LOQ & Reference \\
\hline $\begin{array}{l}\text { Sildenafil, } \\
\text { Tadalafil, } \\
\text { Vardenafil }\end{array}$ & $\begin{array}{l}\text { Standard solutions, } \\
\text { pharmaceutical } \\
\text { dosage forms and } \\
\text { herbal products }\end{array}$ & $\begin{array}{l}\text { Tablet samples and } \\
\text { herbal products } \\
\text { Mixed with } 50 \mathrm{~mL} \text { of } \\
\text { ACN: water } 50: 50(v / v) \text {, } \\
\text { sonication for } 15 \mathrm{~min} \\
\text { and filtration through a } \\
0.45 \mu \mathrm{m} \text { syringe filter }\end{array}$ & LC-ESI-MS/MS & $\begin{array}{c}\text { Sildenafil, } \\
\text { Tadalafil, } \\
\text { Vardenafil } \\
\text { LLOQ: } 20 \text { ng mL }\end{array}$ & [101] \\
\hline $\begin{array}{l}\text { Sildenafil, } \\
\text { Tadalafil, } \\
\text { Vardenafil, } \\
\text { Avanafil }\end{array}$ & $\begin{array}{l}\text { Standard solutions, } \\
\text { urine samples and } \\
\text { illicit medications }\end{array}$ & $\begin{array}{c}\text { Urine samples } \\
\text { Dilution of urine } \\
\text { samples in ultrapure } \\
\text { water }(1: 10) \text {, filtration } \\
\text { through a } 0.22 \mu \mathrm{m} \\
\text { syringe filter and } \\
\text { spiking with standard } \\
\text { solutions. } \\
\text { Illicit medications } \\
\text { Homogenisation of pills, } \\
\text { dissolution in ultrapure } \\
\text { water, sonication for } \\
30 \text { min and filtration } \\
\text { with a } 0.22 \mu \mathrm{m} \\
\text { syringe filter. }\end{array}$ & LC-qTOF-MS/MS & $\begin{array}{c}\text { Sildenafil } \\
\text { LOD: } 2.19 \mathrm{ng} \mathrm{g}^{-1} \\
\text { LOQ: } 7.28 \mathrm{ng} \mathrm{g}^{-1} \\
\text { Tadalafil } \\
\text { LOD: } 9.81 \mathrm{ng} \mathrm{g}^{-1} \\
\text { LOQ: } 32.71 \mathrm{ng} \mathrm{g}^{-1} \\
\text { Vardenafil } \\
\text { LOD: } 2.28 \mathrm{ng} \mathrm{g}^{-1} \\
\text { LOQ: } 7.59 \mathrm{ng} \mathrm{g}^{-1} \\
\text { Avanafil } \\
\text { LOD: } 1.63 \mathrm{ng} \mathrm{g}^{-1} \\
\text { LOQ: } 5.43 \mathrm{ng} \mathrm{g}^{-1}\end{array}$ & [104] \\
\hline Sildenafil & Wastewater samples & $\begin{array}{c}\text { Solid-phase } \\
\text { extraction (SPE) }\end{array}$ & SPE-LC-MS/MS & Not reported & [106] \\
\hline $\begin{array}{l}\text { Sildenafil \& } \\
\text { N-desmethyl } \\
\text { sildenafil }\end{array}$ & $\begin{array}{l}\text { Surface water and } \\
\text { drinking water }\end{array}$ & $\begin{array}{l}\text { Solid-phase } \\
\text { extraction (SPE) }\end{array}$ & UHPLC-MS/MS & $\begin{array}{l}\text { Sildenafil } \\
\text { Surface water } \\
\text { LOD: } 1.0 \mathrm{pg} \mathrm{L}^{-1} \\
\text { LOQ: } 0.9 \mathrm{ng} \mathrm{L}^{-1} \\
\text { Drinking water } \\
\text { LOD: } 1.0 \mathrm{pg} \mathrm{L}^{-1} \\
\text { LOQ: } 0.8 \mathrm{ng} \mathrm{L}^{-1} \\
\text { N-desmethyl } \\
\text { sildenafil } \\
\text { Surface water } \\
\text { LOD: } 1.0 \mathrm{pg} \mathrm{L}^{-1} \\
\text { LOQ: } 1.4 \mathrm{ng} \mathrm{L}^{-1} \\
\text { Drinking water } \\
\text { LOD: } 1.0 \mathrm{pg} \mathrm{L}^{-1} \\
\text { LOQ: } 1.3 \mathrm{ng} \mathrm{L}^{-1}\end{array}$ & [107] \\
\hline $\begin{array}{l}\text { Homosildenafil, } \\
\text { Hydroxyhomo- } \\
\text { sildenafil, } \\
\text { Norneosilde- } \\
\text { nafil, } \\
\text { Thiosildenafil }\end{array}$ & $\begin{array}{c}\text { Artificial freshwater } \\
\text { \& wastewater } \\
\text { samples }\end{array}$ & $\begin{array}{l}\text { Irradiation of tests } \\
\text { solution in artificial } \\
\text { freshwater with an } \\
\text { initial concentration of } \\
10 \mathrm{mg} \mathrm{L}^{-1} \text { and } 1 \mu \mathrm{g} \mathrm{L}{ }^{-1} \\
\text { Wastewater samples } \\
\text { Liquid-liquid extraction }\end{array}$ & $\begin{array}{l}\text { UHPL-ESI- } \\
\text { MS/MS }\end{array}$ & Not reported & [108] \\
\hline
\end{tabular}


Table 9. Cont.

\begin{tabular}{|c|c|c|c|c|c|}
\hline $\begin{array}{l}\text { Investigated } \\
\text { Compound }\end{array}$ & Sample Matrix & Sample Preparation & Detection Method & LOD/LOQ & Reference \\
\hline $\begin{array}{l}\text { Sildenafil and } \\
\text { Vardenafil }\end{array}$ & $\begin{array}{l}\text { Phosphate buffer } \\
\qquad(\mathrm{pH}=7.4)\end{array}$ & $\begin{array}{l}\text { Irradiation of tests } \\
\text { solution in } 5 \mathrm{mM} \\
\text { phosphate buffer diluted } \\
\text { with distilled water, } \\
\text { with an initial } \\
\text { concentration of } \\
10 \mathrm{mg} \mathrm{L}^{-1}\end{array}$ & LC-ESI-MS/MS & Not reported & [109] \\
\hline $\begin{array}{c}\text { Sildenafil, } \\
\text { Tadalafil, } \\
\text { Vardenafil and } \\
\text { their } \\
\text { metabolites }\end{array}$ & $\begin{array}{l}\text { Spiked wastewater } \\
\text { samples }\end{array}$ & $\begin{array}{l}\text { Homogenisation and } \\
\text { filtration through } 0.2 \mu \mathrm{m} \\
\text { cellulose filter }\end{array}$ & $\begin{array}{c}\text { HPLC-(QqQ)- } \\
\text { MS/MS }\end{array}$ & $\begin{array}{c}\text { Sildenafil } \\
\text { LOD: } 1.8 \mathrm{ng} \mathrm{L}^{-1} \\
\text { LOQ: } 6 \mathrm{ng} \mathrm{L}^{-1} \\
\text { Tadalafil } \\
\text { LOD: } 2.3 \mathrm{ng} \mathrm{L}^{-1} \\
\text { LOQ: } 7.5 \mathrm{ng} \mathrm{L}^{-1} \\
\text { Vardenafil } \\
\text { LOD: } 7.2 \mathrm{ng} \mathrm{L}^{-1} \\
\text { LOQ: } 24 \mathrm{ng} \mathrm{L}^{-1}\end{array}$ & [110] \\
\hline
\end{tabular}

\section{Conclusions and Future Perspectives}

The potential effects of PDE-5 inhibitors on the environment are not still apparent. However, ED medicines will prove to have very high usage rates in the near future, mainly because they are very diffuse and popular drugs. The availability of EDs without prescription over the Internet and their use for ludic activity can yield an increased potential for environmental exposure and conceivable non-target effects.

Risk is connected principally to the accumulation, persistence and toxicity of pharmaceutical compounds diffused in the environment rather than the actual quantity released. Given their bioactive nature, even small amounts of this kind of drug could impact delicate organisms; in addition, synergic action with other contaminants might have additive effects once released into the environment, especially if they insist on the same receptors of biological organisms.

Since these substances are rapidly becoming one of the most widespread and extensively used drugs at the world level, improper disposal in the environment is a reason of general concern.

More detailed knowledge of biotic and abiotic processes, able to interfere with these pollutants, will notably improve the used remediation strategies.

Author Contributions: Conceptualisation, S.A.B. and L.S.; Biological data curation, L.S., D.C. and M.B.; Chemical data curation G.B., R.P., L.F.; Formal data reviewing, F.L. and L.S.; Methodology, L.S., R.P., G.B.; Resources, S.A.B.; Writing—original draft, L.F. and L.S.; Writing-review and editing, S.A.B. All authors have read and agreed to the published version of the manuscript.

Funding: This research received no external funding.

Institutional Review Board Statement: Not Applicable.

Informed Consent Statement: Not Applicable.

Data Availability Statement: Not applicable.

Acknowledgments: We are grateful to the BIOMON fund for its economic support.

Conflicts of Interest: The authors declare no conflict of interest. 


\section{References}

1. Geissen, V.; Mol, H.; Klumpp, E.; Umlauf, G.; Nadal, M.; van der Ploeg, M.; van de Zee, S.E.A.T.M.; Ritsema, C.J. Emerging pollutants in the environment: A challenge for water resource management. Int. Soil Water Conserv. Res. 2015, 3, 57-65. [CrossRef]

2. Tran, N.H.; Reinhard, M.; Yew-Hoong Gin, K. Occurrence and fate of emerging contaminants in municipal wastewater treatment plants from different geographical regions-A review. Water Res. 2017, 133, 182-207. [CrossRef]

3. Zuccato, E.; Calamari, D.; Natangelo, M.; Fanelli, R. Presence of therapeutic drugs in the environment. Lancet 2000, 355, 1789-1790. [CrossRef]

4. Susa, S.T.; Preuss, C.V. Drug Metabolism. In StatPearls [Internet]; StatPearls Publishing: Treasure Island, FL, USA, 2021.

5. Halling-Sørensen, B.; Nors Nielsen, S.; Lanzky, P.F.; Ingerslev, F.; Holten Lützhøft, H.C.; Jørgensen, S.E. Occurrence, fate and effects of pharmaceutical substances in the environment-A review. Chemosphere 1998, 36, 357-393. [CrossRef]

6. Zhou, J.; Broodbank, N. Sediment-water interactions of pharmaceutical residues in the river environment. Water Res. 2014, 48 , 61-70. [CrossRef]

7. Castiglioni, S.; Bagnati, R.; Fanelli, R.; Pomati, F.; Calamari, D.; Zuccato, E. Removal of pharmaceuticals in sewage treatment plants in Italy. Environ. Sci. Technol. 2006, 40, 357-363. [CrossRef]

8. Buser, H.R.; Müller, M.D.; Theobald, N. Occurrence of the pharmaceutical drug clofibric acid and the herbicide mecoprop in various Swiss Lakes and in the North Sea. Environ. Sci. Technol. 1998, 32, 188-192. [CrossRef]

9. Calamari, D.; Zuccato, E.; Castiglioni, S.; Bagnati, R.; Fanelli, R. Strategic survey of therapeutic drugs in the rivers Po and Lambro in Northern Italy. Environ. Sci. Technol. 2003, 37, 1241-1248. [CrossRef]

10. Cedergreen, N. Quantifying synergy: A systematic review of mixture toxicity studies within environmental toxicology. PLoS ONE 2014, 9, e96580. [CrossRef]

11. Hernández, A.F.; Gil, F.; Lacasaña, M. Toxicological interactions of pesticide mixtures: An update. Arch. Toxicol. 2017, 91, 3211-3223. [CrossRef]

12. Davies, J.; Davies, D. Origins and Evolution of Antibiotic Resistance. Microbiol. Mol. Biol. Rev. 2010, 74, 1092-2172. [CrossRef] [PubMed]

13. Directive 2008/105/EC of the European Parliament and of the Council of 16 December 2008 on Environmental Quality Standards in the Field of Water Policy. 2008. Available online: https:/ / eur-lex.europa.eu/eli/dir/2008/105/oj (accessed on 4 May 2020).

14. European Union. Commission Implementing Decision (EU) 2018/840 of 5 June 2018 Establishing a Watch List of Substances for Union-Wide Monitoring in the Field of Water Policy Pursuant to Directive 2008/105/EC of the European Parliament and of the Council and Repealing Commission Implementing Decision (EU) 2015/495 (Notified under Document C(2018) 3362.2018. Available online: https:/ / eur-lex.europa.eu/eli/dec_impl/2018/840/oj (accessed on 4 May 2020).

15. Nieto, A.; Peschka, M.; Borrull, F.; Pocurull, E.; Marcé, R.M.; Knepper, T.P. Phosphodiesterase type V inhibitors: Occurrence and fate in wastewater and sewage sludge. Water Res. 2010, 44, 1607-1615. [CrossRef] [PubMed]

16. Mas, M. Molecular mechanisms of penile erection. Arch. Esp. Urol. 2010, 63, 589-598. [PubMed]

17. White, A. The State of Men's Health in Europe: Extended Report; European Union: Brussels, Belgium, 2011; ISBN 978-92-79-20167-7. [CrossRef]

18. Goldstein, I.; Burnett, A.L.; Rosen, R.C.; Park, P.W.; Stecher, V.J. The Serendipitous Story of Sildenafil: An Unexpected Oral Therapy for Erectile Dysfunction. Sex. Med. Rev. 2019, 7, 115-128. [CrossRef]

19. Maiorino, M.I.; Bellastella, G.; Esposito, K. Lifestyle modifications and erectile dysfunction: What can be expected? Asian J. Androl. 2015, 17, 5-10. [CrossRef] [PubMed]

20. Maiorino, M.I.; Bellastella, G.; Esposito, K. Diabetes and sexual dysfunction: Current perspectives. Diabetes Metab. Syndr. Obes. Targets Ther. 2014, 7, 95-105. [CrossRef]

21. Yafi, F.A.; Jenkins, L.; Albersen, M.; Corona, G.; Isidori, A.M.; Goldfarb, S.; Maggi, M.; Nelson, C.J.; Parish, S.; Salonia, A.; et al. Erectile dysfunction. Nat. Rev. Dis. Prim. 2016, 2, 1-20. [CrossRef] [PubMed]

22. Taichman, D.B.; Ornelas, J.; Chung, L.; Klinger, J.R.; Lewis, S.; Mandel, J.; Palevsky, H.I.; Rich, S.; Sood, N.; Rosenzweig, E.B.; et al. Pharmacologic therapy for pulmonary arterial hypertension in adults: CHEST guideline and expert panel report. Chest 2014, 146, 449-475. [CrossRef]

23. Rashid, J.; Patel, B.; Nozik-Grayck, E.; McMurtry, I.F.; Stenmark, K.R.; Ahsan, F. Inhaled sildenafil as an alternative to oral sildenafil in the treatment of pulmonary arterial hypertension (PAH). J. Control. Release 2017, 250, 96-106. [CrossRef]

24. Chiang, J.; Yafi, F.A.; Dorsey, P.J.; Hellstrom, W.J.G. The dangers of sexual enhancement supplements and counterfeit drugs to "treat" erectile dysfunction. Transl. Androl. Urol. 2017, 6, 12-19. [CrossRef]

25. Venhuis, B.J.; De Voogt, P.; Emke, E.; Causanilles, A.; Keizers, P.H.J. Success of rogue online pharmacies: Sewage study of sildenafil in the Netherlands. Br. Med. J. 2014, 349, g4317. [CrossRef]

26. Keizers, P.H.J.; Wiegard, A.; Venhuis, B.J. The quality of sildenafil active substance of illegal source. J. Pharm. Biomed. Anal. 2016, 131, 133-139. [CrossRef]

27. Italian Medicine Agency. National Report on Medicines Use in Italy: Year 2018; Italian Medicine Agency: Rome, Italy, 2018.

28. Dhaliwal, A.; Gupta, M. PDE5 Inhibitor. In StatPearls [Internet]; StatPearls Publishing: Treasure Island, FL, USA, 2021; Available online: http:/ / www.ncbi.nlm.nih.gov /books/nbk549843/ (accessed on 2 September 2021).

29. Ghofrani, H.A.; Osterloh, I.H.; Grimminger, F. Sildenafil: From angina to erectile dysfunction to pulmonary hypertension and beyond. Nat. Rev. Drug Discov. 2006, 5, 689-702. [CrossRef] [PubMed] 
30. Huang, S.A.; Lie, J.D. Phosphodiesterase-5 (PDE5) inhibitors in the management of erectile dysfunction. Pharm. Ther. 2013, 38, 407-419. Available online: https:/ / www.ncbi.nlm.nih.gov/pmc/articles/PMC3776492/ (accessed on 2 September 2021).

31. Nichols, D.J.; Muirhead, G.J.; Harness, J.A. Pharmacokinetics of sildenafil citrate after single oral doses in healthy male subjects: Absolute bioavailability, food effects and dose proportionality. Br. J. Clin. Pharmacol. Suppl. 2002, 53, 5S-12S. [CrossRef]

32. Stark, S.; Sachse, R.; Liedl, T.; Hensen, J.; Rohde, G.; Wensing, G.; Horstmann, R.; Schrott, K.M. Vardenafil increases penile rigidity and tumescence in men with erectile dysfunction after a single oral dose. Eur. Urol. 2001, 40, 181-190. [CrossRef]

33. Jung, J.; Choi, S.; Cho, S.H.; Ghim, J.L.; Hwang, A.; Kim, U.; Kim, B.S.; Koguchi, A.; Miyoshi, S.; Okabe, H.; et al. Tolerability and pharmacokinetics of avanafil, a phosphodiesterase type 5 inhibitor: A single- and multiple-dose, double-blind, randomised, placebo-controlled, dose-escalation study in healthy Korean male volunteers. Clin. Ther. 2010, 32, 1178-1187. [CrossRef] [PubMed]

34. Patterson, B.; Bedding, A.; Jewelll, H.; Payne, C.; Mitchell, M. The effect of intrinsic and extrinsic factors on the pharmacokinetic properties of tadalafil (IC351). Int. J. Impot. Res. 2001, 13, S62.

35. Pfizer Labs. VIAGRA (Sildenafil Citrate); Pfizer: New York, NY, USA, 2010.

36. Bayer HealthCare. LEVITRA (Vardenafil HCl); Bayer Pharmaceuticals Corporation: West Haven, CT, USA, 2014.

37. Vivus. STENDRA (Avanafil); Vivus: Campbell, CA, USA, 2012.

38. Shim, Y.S.; Pae, C.U.; Cho, K.J.; Kim, S.W.; Kim, J.C.; Koh, J.S. Effects of daily low-dose treatment with phosphodiesterase type 5 inhibitor on cognition, depression, somatisation and erectile function in patients with erectile dysfunction: A double-blind, placebo-controlled study. Int. J. Impot. Res. 2014, 26, 76-80. [CrossRef]

39. Schnetzler, G.; Banks, I.; Kirby, M.; Zou, K.H.; Symonds, T. Characteristics, behaviors, and attitudes of men bypassing the healthcare system when obtaining phosphodiesterase type 5 inhibitors. J. Sex. Med. 2010, 7, 1237-1246. [CrossRef]

40. Gaudiano, M.C.; Manna, L.; Rodomonte, A.L.; Bartolomei, M.; Bertocchi, P.; Gallinella, B.; Antoniella, E.; Muleri, N.; Civitelli, G.; Alimonti, S.; et al. A Survey on Illegal and Counterfeit Medicines for the Treatment of Erectile Dysfunctions in Italy. J. Sex. Med. 2012, 9, 2130-2137. [CrossRef]

41. Mustazza, C.; Gaudiano, M.C.; Borioni, A.; Valvo, L. The evolution of the illegal market of falsified medicines and the experience of the Italian OMCL: From control to research. Ann. Dell'istituto Super. Sanita 2018, 54, 267-269. [CrossRef]

42. European Union. Directive 2011/62/EU of the European Parliament and of the Council of 8 June 2011 Amending Directive 2001/83/EC on the Community Code Relating to Medicinal Products for Human Use; European Union: Brussels, Belgium, 2011.

43. Kee, C.L.; Ge, X.; Gilard, V.; Malet-Martino, M.; Low, M.Y. A review of synthetic phosphodiesterase type 5 inhibitors (PDE-5i) found as adulterants in dietary supplements. J. Pharm. Biomed. Anal. 2018, 147, 250-277. [CrossRef]

44. Causanilles, A.; Rojas Cantillano, D.; Emke, E.; Bade, R.; Baz-Lomba, J.A.; Castiglioni, S.; Castrignanò, E.; Gracia-Lor, E.; Hernández, F.; Kasprzyk-Hordern, B.; et al. comparison of phosphodiesterase type V inhibitors use in eight European cities through analysis of urban wastewater. Environ. Int. 2018, 115, 279-284. [CrossRef] [PubMed]

45. Schröder, H.F.; Gebhardt, W.; Thevis, M. Anabolic, doping, and lifestyle drugs, and selected metabolites in wastewater-detection, quantification, and behaviour monitored by high-resolution MS and MS n before and after sewage treatment. Anal. Bioanal. Chem. 2010, 398, 1207-1229. [CrossRef] [PubMed]

46. Papageorgiou, M.; Kosma, C.; Lambropoulou, D. Seasonal occurrence, removal, mass loading and environmental risk assessment of 55 pharmaceuticals and personal care products in a municipal wastewater treatment plant in Central Greece. Sci. Total Environ. 2016, 543, 547-569. [CrossRef] [PubMed]

47. Temussi, F.; DellaGreca, M.; Pistillo, P.; Previtera, L.; Zarrelli, A.; Criscuolo, E.; Lavorgna, M.; Russo, C.; Isidori, M. Sildenafil and tadalafil in simulated chlorination conditions: Ecotoxicity of drugs and their derivatives. Sci. Total Environ. 2013, 463, 366-373. [CrossRef] [PubMed]

48. Eichhorn, P.; Pérez, S.; Aceña, J.; Gardinali, P.; Abad, J.L.; Barceló, D. Identification of phototransformation products of sildenafil (Viagra) and its N-demethylated human metabolite under simulated sunlight. J. Mass Spectrom. 2012, 47, 701-711. [CrossRef]

49. Arditsoglou, A.; Voutsa, D. Partitioning of endocrine disrupting compounds in inland waters and wastewaters discharged into the coastal area of Thessaloniki, Northern Greece. Environ. Sci. Pollut. Res. 2010, 17, 529-538. [CrossRef]

50. Fent, K.; Weston, A.A.; Caminada, D. Ecotoxicology of human pharmaceuticals. Aquat. Toxicol. 2006, 76, 122-159. [CrossRef]

51. Kolpin, D.W.; Furlong, E.T.; Meyer, M.T.; Thurman, E.M.; Zaugg, S.D.; Barber, L.B.; Buxton, H.T. Pharmaceuticals, hormones, and other organic wastewater contaminants in US streams, 1999-2000: A national reconnaissance. Environ. Sci. Technol. 2002, 36, 1202-1211. [CrossRef]

52. Stasinakis, A.S.; Gatidou, G.; Mamais, D.; Thomaidis, N.S.; Lekkas, T.D. Occurrence and fate of endocrine disrupters in Greek sewage treatment plants. Water Res. 2008, 42, 1796-1804. [CrossRef]

53. Deblonde, T.; Cossu-Leguille, C.; Hartemann, P. Emerging pollutants in wastewater: A review of the literature. Int. J. Hyg. Environ. Health 2011, 214, 442-448. [CrossRef] [PubMed]

54. Ma, R.; Wang, B.; Yin, L.; Zhang, Y.; Deng, S.; Huang, J.; Wang, Y.; Yu, G. Characterization of pharmaceutically active compounds in Beijing, China: Occurrence pattern, spatiotemporal distribution and its environmental implication. J. Hazard. Mater. 2017, 323, 147-155. [CrossRef] [PubMed]

55. Rivera-Utrilla, J.; Sánchez-Polo, M.; Ferro-García, M.Á.; Prados-Joya, G.; Ocampo-Pérez, R. Pharmaceuticals as emerging contaminants and their removal from water. A review. Chemosphere 2013, 93, 1268-1287. [CrossRef]

56. Coimbra, R.N.; Calisto, V.; Ferreira, C.I.A.; Esteves, V.I.; Otero, M. Removal of pharmaceuticals from municipal wastewater by adsorption onto pyrolysed pulp mill sludge. Arab. J. Chem. 2019, 12, 3611-3620. [CrossRef] 
57. Jaria, G.; Calisto, V.; Silva, C.P.; Gil, M.V.; Otero, M.; Esteves, V.I. Obtaining granular activated carbon from paper mill sludgeA challenge for application in the removal of pharmaceuticals from wastewater. Sci. Total Environ. 2019, 653, 393-400. [CrossRef]

58. Husein, D.Z.; Hassanien, R.; Al-Hakkani, M.F. Green-synthesized copper nano-adsorbent for the removal of pharmaceutical pollutants from real wastewater samples. Heliyon 2019, 5, e02339. [CrossRef]

59. Delgado, N.; Capparelli, A.; Navarro, A.; Marino, D. Pharmaceutical emerging pollutants removal from water using powdered activated carbon: Study of kinetics and adsorption equilibrium. J. Environ. Manag. 2019, 236, 301-308. [CrossRef]

60. Oulton, R.L.; Kohn, T.; Cwiertny, D.M. Pharmaceuticals and personal care products in effluent matrices: A survey of transformation and removal during wastewater treatment and implications for wastewater management. J. Environ. Monit. 2010, 12, 1956-1978. [CrossRef]

61. Doll, T.E.; Frimmel, F.H. Fate of pharmaceuticals—Photodegradation by simulated solar UV-light. Chemosphere 2003, 52, 1757-1769. [CrossRef]

62. Escher, B.I.; Fenner, K. Recent advances in environmental risk assessment of transformation products. Environ. Sci. Technol. 2011, 45, 3835-3847. [CrossRef]

63. De Rosa, M.; Ledia Triana Alonso, J. Studies of the Mechanism of Chlorination of Indoles. Detection of IV-Chloroindole and 3-Chloro-3H-indole as Intermediates. J. Org. Chem. 1978, 43, 2639-2643. [CrossRef]

64. De Felice, B.; Argenziano, C.; Guida, M.; Trifuoggi, M.; Russo, F.; Condorelli, V.; Inglese, M. Molecular characterisation of microbial population dynamics during sildenafil citrate degradation. Mol. Biotechnol. 2009, 41, 123-132. [CrossRef]

65. Grossberger, A.; Hadar, Y.; Borch, T.; Chefetz, B. Biodegradability of pharmaceutical compounds in agricultural soils irrigated with treated wastewater. Environ. Pollut. 2014, 185, 168-177. [CrossRef]

66. Isidori, M.; Nardelli, A.; Pascarella, L.; Rubino, M.; Parrella, A. Toxic and genotoxic impact of fibrates and their photoproducts on non-target organisms. Environ. Int. 2007, 33, 635-641. [CrossRef] [PubMed]

67. Isidori, M.; Parrella, A.; Pistillo, P.; Temussi, F. Effects of ranitidine and its photoderivatives in the aquatic environment. Environ. Int. 2009, 35, 821-825. [CrossRef] [PubMed]

68. Vasquez, M.I.; Garcia-Käufer, M.; Hapeshi, E.; Menz, J.; Kostarelos, K.; Fatta-Kassinos, D.; Kümmerer, K. Chronic ecotoxic effects to Pseudomonas putida and Vibrio fischeri, and cytostatic and genotoxic effects to the hepatoma cell line (HepG2) of ofloxacin photo(cata)lytically treated solutions. Sci. Total Environ. 2013, 450, 356-365. [CrossRef] [PubMed]

69. Rocco, L.; Frenzilli, G.; Zito, G.; Archimandritis, A.; Peluso, C.; Stingo, V. Genotoxic effects in fish induced by pharmacological agents present in the sewage of some Italian water-treatment plants. Environ. Toxicol. 2012, 27, 18-25. [CrossRef] [PubMed]

70. Zanuri, N.B.M.; Bentley, M.G.; Caldwell, G.S. Assessing the impact of diclofenac, ibuprofen and sildenafil citrate (Viagra ${ }^{\circledR}$ ) on the fertilisation biology of broadcast spawning marine invertebrates. Mar. Environ. Res. 2017, 127, 126-136. [CrossRef] [PubMed]

71. Su, Y.H.; Vacquier, V.D. Cyclic GMP-specific phosphodiesterase-5 regulates motility of sea urchin spermatozoa. Mol. Biol. Cell 2006, 17, 114-121. [CrossRef] [PubMed]

72. Schnurstein, A.; Braunbeck, T. Tail moment versus tail length-Application of an in vitro version of the comet assay in biomonitoring for genotoxicity in native surface waters using primary hepatocytes and gill cells from zebrafish (Danio rerio). Ecotoxicol. Environ. Saf. 2001, 49, 187-196. [CrossRef] [PubMed]

73. Diekmann, M.; Waldmann, P.; Schnurstein, A.; Grummt, T.; Braunbeck, T.; Nagel, R. On the relevance of genotoxicity for fish populations II: Genotoxic effects in zebrafish (Danio rerio) exposed to 4-nitroquinoline-1-oxide in a complete life-cycle test. Aquat. Toxicol. 2004, 68, 27-37. [CrossRef] [PubMed]

74. Kari, G.; Rodeck, U.; Dicker, A.P. Zebrafish: An emerging model system for human disease and drug discovery. Clin. Pharmacol. Ther. 2007, 82, 70-80. [CrossRef] [PubMed]

75. Hafez, E.M.; Shiekh, R.E.; Amin, A.S.; Gouda, A.A. Cloud point extraction of vardenafil $\mathrm{HCl}$ from pharmaceutical formulations prior to spectrophotometric determination. Int. J. Res. Pharm. Pharm. Sci. 2017, 2, 3-10.

76. Reddy, T.V. Spectrophotometric quantification of vardenafil in bulk and tablet. Int. J. Biol. Chem. Sci. 2015, 3, 185-192.

77. Sunil Kumar, A.V.V.N.K.; Reddy, T.V.; Sekaran, C.B. Spectrophotometric analysis of vardenafil in tablet dosage forms by using electrophilic coupling reagents. Anal. Bioanal. Chem. Res. 2016, 3, 29-39. [CrossRef]

78. El Sheikh, R.; Gouda, A.A.; Abo, S.; Ezz, A.L. Utilitization of Charge Transfer Complexation Reaction for the Spectrophotometric Determination of Vardenafil $\mathrm{HCl}$ and Yohimbin $\mathrm{HCl}$ in Pharmaceutical Formulations. Chem. Sci. 2016, 5, 986-1000. [CrossRef]

79. Sakur, A.A.; Affas, S. Validated Spectrophotometric Method to Determine Vardenafil and Sildenafil in Pharmaceutical Forms Using Potassium Iodide and Potassium Iodate. Int. J. Pharm. Pharm. Sci. 2017, 9, 65-69. [CrossRef]

80. Ahmed, N.R.; Ahmed, I.A.; Qasim, H.Y. Ultra-Sensitive Estimation of Vardenafil. Hcl in Pharmaceutical Preparations and Environmental Waste Water Samples. Eur. J. Biomed. Pharm. Sci. 2020, 7, 85-89.

81. Idris, A.M.; Alnajjar, A.O. Multi-response optimisation of a capillary electrophoretic method for determination of vardenafil in the bulk drug and in a tablet formulation. Acta Chromatogr. 2007, 19, 97-109.

82. Mohamed, S.K.; Shalaby, N.M. Microdetermination of sildenafil, tadalafil and vardenafil drugs employed in the erectile dysfunction therapy in pharmaceutical formulations and urine samples of diabetic patients type-II in taif area, saudia arabia using atomic emission and atomic absorp. Int. J. Pharma Bio Sci. 2013, 4, 1037-1046.

83. Manisha, G.; Usha, P.; Vandana, P. Development and validation of RP-HPLC method for estimation of vardenafil in bulk and pharmaceutical formulation. Am. J. PharmTech Res. 2013, 3, 928-938. 
84. Di, Y.; Zhao, M.; Nie, Y.; Wang, F.; Lv, J. A High-Performance Liquid Chromatography: Chemiluminescence Method for Potential Determination of Vardenafil in Dietary Supplement. J. Autom. Methods Manag. Chem. 2011, 2011. [CrossRef]

85. Nickum, E.A.; Flurer, C.L. Determination of phosphodiesterase-5 inhibitors and analogs using high-performance liquid chromatography with ultraviolet detection. J. Chromatogr. Sci. 2015, 53, 38-46. [CrossRef]

86. Carlucci, G.; Palumbo, P.; Iuliani, P.; Palumbo, G. Development of a method for the determination of vardenafil in human plasma by high performance liquid chromatographywith UV detection. Biomed. Chromatogr. 2009, 23, 759-763. [CrossRef]

87. Kumar, K.K.; Rao, C.K.; Rama, Y.; Reddy, K.; Mukkanti, K. A Validated Rapid Stability-Indicating Method for the Determination of Related Substances in Vardenafil Hydrochloride by Ultra-Performance Liquid Chromatography. Am. J. Anal. Chem. 2012, 3 , 59-66. [CrossRef]

88. Jeong, Y.; Suh, S.I.; Kim, J.Y.; In, M.K.; Paeng, K.J. Simultaneous Determination of Sildenafil, Tadalafil, and Vardenafil in Pharmaceutical Preparations by High-Temperature Gas Chromatography/Mass Spectrometry. Chromatographia 2016, 79, 16711678. [CrossRef]

89. Mokhtar, S.U.; Chin, S.T.; Kee, C.L.; Low, M.Y.; Drummer, O.H.; Marriott, P.J. Rapid determination of sildenafil and its analogues in dietary supplements using gas chromatography-triple quadrupole mass spectrometry. J. Pharm. Biomed. Anal. 2016, 121, 188-196. [CrossRef]

90. Man, C.N.; Nor, N.M.; Lajis, R.; Harn, G.L. Identification of sildenafil, tadalafil and vardenafil by gas chromatography-mass spectrometry on short capillary column. J. Chromatogr. A 2009, 1216, 8426-8430. [CrossRef]

91. Saisho, K.; Scott, K.S.; Morimoto, S.; Nakahara, Y. Hair analysis for pharmaceutical drugs. II. Effective extraction and determination of sildenafil $\left(\right.$ Vigra $^{\circledR}$ ) and its N-desmethyl metabolite in rat and human hair by GC-MS. Biol. Pharm. Bull. 2001, 24, 1384-1388. [CrossRef]

92. Acquavia, M.A.; Foti, L.; Pascale, R.; Nicolò, A.; Brancaleone, V.; Cataldi, T.R.I.; Martelli, G.; Scrano, L.; Bianco, G. Detection and quantification of COVID-19 antiviral drugs in biological fluids and tissues. Talanta 2021, 224, 121862. [CrossRef] [PubMed]

93. Baokar, S.; Pawar, V.; Patil, R.; Jagatap, R.; Ekatpure, N. Validation of simple and rapid UV-spectrophotometric method with stress degradation study for sildenafil citrate. Res. J. Pharm. Technol. 2012, 5, 214-218.

94. Sakur, A.; Affas, S. Simple and Sensitive Spectrophotometric Determination of Sildenafil Citrate in Pharmaceutical Formulations. Res. J. Pharm. Technol. 2017, 10, 4242-4246. [CrossRef]

95. Salem, H.; Abdel Aziz, B.E. Utility of Gold Nanoparticles for Spectrofluorimetric and Spectrophotometric Determination of Sildenafil Citrate, Dapoxetine, Vardenafil and Tadalafil in their Dosage Forms and Biological Fluids. Anal. Chem. Lett. 2020, 10, 321-335. [CrossRef]

96. Fidan, A.K.; Bakirdere, S. Simultaneous determination of sildenafil and tadalafil in legal drugs, illicit/counterfeit drugs, and wastewater samples by high-performance liquid chromatography. J. AOAC Int. 2016, 99, 923-928. [CrossRef] [PubMed]

97. Fejos, I.; Neumajer, G.; Béni, S.; Jankovics, P. Qualitative and quantitative analysis of PDE-5 inhibitors in counterfeit medicines and dietary supplements by HPLC-UV using sildenafil as a sole reference. J. Pharm. Biomed. Anal. 2014, 98, 327-333. [CrossRef]

98. Patel, D.N.; Li, L.; Kee, C.L.; Ge, X.; Low, M.Y.; Koh, H.L. Screening of synthetic PDE-5 inhibitors and their analogues as adulterants: Analytical techniques and challenges. J. Pharm. Biomed. Anal. 2014, 87, 176-190. [CrossRef] [PubMed]

99. Liigand, P.; Kaupmees, K.; Haav, K.; Liigand, J.; Leito, I.; Girod, M.; Antoine, R.; Kruve, A. Think Negative: Finding the Best Electrospray Ionization/MS Mode for Your Analyte. Anal. Chem. 2017, 89, 5665-5668. [CrossRef]

100. Öztürk Er, E.; Özbek, B.; Bakırdere, S. A sensitive and selective analytical method for the simultaneous determination of sildenafil and tadalafil in water, energy drinks and sewage sludge matrices by LC-QTOF-MS/MS. Meas. J. Int. Meas. Confed. 2018, 124, 64-71. [CrossRef]

101. Abdel-Hamid, M. Determination of sildenafil, tadalafil, and vardenafil in tablets and adulterated herbal products by ESI-MS-MS. J. Liq. Chromatogr. Relat. Technol. 2006, 29, 591-603. [CrossRef]

102. Zhang, Y.; Huang, Z.; Ding, L.; Yan, H.; Wang, M.; Zhu, S. Simultaneous determination of yohimbine, sildenafil, vardenafil and tadalafil in dietary supplements using high-performance liquid chromatography-tandem mass spectrometry. J. Sep. Sci. 2010, 33, 2109-2114. [CrossRef]

103. De Orsi, D.; Pellegrini, M.; Marchei, E.; Nebuloni, P.; Gallinella, B.; Scaravelli, G.; Martufi, A.; Gagliardi, L.; Pichini, S. High performance liquid chromatography-diode array and electrospray-mass spectrometry analysis of vardenafil, sildenafil, tadalafil, testosterone and local anesthetics in cosmetic creams sold on the Internet web sites. J. Pharm. Biomed. Anal. 2009, 50, 362-369. [CrossRef] [PubMed]

104. Öztürk Er, E.; Özbek, B.; Bakırdere, S. Accurate and sensitive determination of sildenafil, tadalafil, vardenafil, and avanafil in illicit erectile dysfunction medications and human urine by LC with quadrupole-TOF-MS/MS and their behaviors in simulated gastric conditions. J. Sep. Sci. 2019, 42, 475-483. [CrossRef]

105. Baker, D.R.; Kasprzyk-Hordern, B. Critical evaluation of methodology commonly used in sample collection, storage and preparation for the analysis of pharmaceuticals and illicit drugs in surface water and wastewater by solid phase extraction and liquid chromatography-mass spectrometry. J. Chromatogr. A 2011, 1218, 8036-8059. [CrossRef]

106. 1Baker, D.R.; Barron, L.; Kasprzyk-Hordern, B. Illicit and pharmaceutical drug consumption estimated via wastewater analysis. Part A: Chemical analysis and drug use estimates. Sci. Total Environ. 2014, 487, 629-641. [CrossRef] 
107. Boleda, M.R.; Galceran, M.T.; Ventura, F. Validation and uncertainty estimation of a multiresidue method for pharmaceuticals in surface and treated waters by liquid chromatography-tandem mass spectrometry. J. Chromatogr. A 2013, 1286, 146-158. [CrossRef] [PubMed]

108. Aceña, J.; Pérez, S.; Gardinali, P.; Abad, J.L.; Eichhorn, P.; Heuett, N.; Barceló, D. Structure elucidation of phototransformation products of unapproved analogs of the erectile dysfunction drug sildenafil in artificial freshwater with UPLC-Q Exactive-MS. J. Mass Spectrom. 2014, 49, 1279-1289. [CrossRef] [PubMed]

109. Herbert, L.P.; Becker-Krail, D.B.; Cory, W.C. Persistent phototransformation products of vardenafil (Levitra $\left.{ }^{\circledR}\right)$ and sildenafil (Viagra $\left.{ }^{\circledR}\right)$. Chemosphere 2015, 134, 557-562. [CrossRef]

110. Causanilles, A.; Emke, E.; De Voogt, P. Determination of phosphodiesterase type V inhibitors in wastewater by direct injection followed by liquid chromatography coupled to tandem mass spectrometry. Sci. Total Environ. 2016, 565, 140-147. [CrossRef] 